Published in final edited form as:

Circ Res. 2016 January 22; 118(2): 311-329. doi:10.1161/CIRCRESAHA.115.305043.

\title{
Cardiac Mechano-Gated Ion Channels and Arrhythmias
}

\author{
Remi Peyronnet, $\mathrm{PhD}^{1}$, Jeanne M. Nerbonne, $\mathrm{PhD}^{2}$, and Peter Kohl, MD, PhD, FAHA ${ }^{1,3}$ \\ ${ }^{1}$ National Heart and Lung Institute, Imperial College London, UK \\ ${ }^{2}$ Departments of Developmental Biology and Internal Medicine, Center for Cardiovascular \\ Research, Washington University School of Medicine, St. Louis, USA \\ ${ }^{3}$ Research Centre for Cardiovascular Medicine, University Heart Centre Freiburg/Bad Krozingen, \\ Germany
}

\section{Abstract}

Mechanical forces will have been omnipresent since the origin of life, and living organisms have evolved mechanisms to sense, interpret and respond to mechanical stimuli. The cardiovascular system in general, and the heart in particular, are exposed to constantly changing mechanical signals, including stretch, compression, bending, and shear. The heart adjusts its performance to the mechanical environment, modifying electrical, mechanical, metabolic, and structural properties over a range of time scales. Many of the underlying regulatory processes are encoded intra-cardially, and are thus maintained even in heart transplant recipients. Although mechanosensitivity of heart rhythm has been described in the medical literature for over a century, its molecular mechanisms are incompletely understood. Thanks to modern biophysical and molecular technologies, the roles of mechanical forces in cardiac biology are being explored in more detail, and detailed mechanisms of mechano-transduction have started to emerge.

Mechano-gated ion channels are cardiac mechano-receptors. They give rise to mechano-electric feedback, thought to contribute to normal function, disease development, and, potentially, therapeutic interventions. In this review, we focus on acute mechanical effects on cardiac electrophysiology, explore molecular candidates underlying observed responses, and discuss their pharmaceutical regulation. From this, we identify open research questions and highlight emerging technologies that may help in addressing them.

Cardiac electrophysiology is acutely affected by the heart's mechanical environment. Mechanoelectric feedback affects excitability, conduction, and electrical load, and remains an underestimated player in arrhythmogenesis. The utility of therapeutic interventions targeting acute mechano-electrical transduction is an open field worthy of further study.

\section{Keywords}

heart; mechano-electric feedback; stretch-activated channels; heart rhythm

Corresponding author: Prof. Peter Kohl, Director, Research Centre for Cardiovascular Medicine, University of Freiburg, Elsässer Str. 2q, 79110 Freiburg, Germany, peter.kohl@universitaets-herzzentrum.de, Tel: +44 (0) 1895453807.

Disclosures: none 


\section{Introduction to Cardiac Mechano-Sensitivity}

\section{History and Scope}

The heart's propensity to respond to mechanical stimuli with acute changes in its activity has been known for centuries. Early reports in the European medical literature describing mechanical effects on human heart rhythm date back to the $19^{\text {th }}$ century, such as the communications by Auguste Nélaton and Felice Meola ${ }^{1,2}$ on sudden death caused by precordial impact. ${ }^{3,4}$

At about the same time, Oskar Langendorff ${ }^{5}$ developed his isolated perfused heart model which, by the way, offers vivid illustrations of mechano-sensitivity (e.g. touch-induced ectopy). Building on the Langendorff-method, physiologists like Henry Bowditch, Joseph Coats and Elias Cyon ${ }^{6}$ described effects of cardiac volume loading on contractility, nowadays commonly credited to subsequent defining work by Otto Frank and Ernest Starling. ${ }^{7,8}$ Astonishingly, given the long history and vast importance of this mechanomechanical feedback for auto-regulation of cardiac output, the mechanisms underlying the 'Frank-Starling Effect' are still subject of debate. ${ }^{9}$

In parallel, first experimental evidence of mechano-electrical feedback (MEF) ${ }^{10}$ was reported by Francis Bainbridge, who showed that stretch of the right atrium, containing the heart's primary pacemaker tissue, increases spontaneous beating rate. ${ }^{11}$ This 'Bainbridge effect' is seen in the denervated heart, including human transplants, ${ }^{12-14}$ ex situ animal hearts, ${ }^{15-17}$ isolated tissue, ${ }^{18,19}$ and even single isolated pacemaker cells, ${ }^{20}$ highlighting the intrinsic nature of at least some of the underlying mechanisms. Conceptually related MEF effects are seen in cardiac myocytes ${ }^{21-24}$ and non-myocytes, ${ }^{25-27}$ highlighting the potential relevance of cardiac MEF for heart function (for more detail on MEF, see ${ }^{28}$ ).

This review will focus on one of the contributors to mechanically-induced acute changes in cardiac electrophysiology. Their effects are instantaneous, as opposed to more slowly occurring mechanical modulation of contractility, or even longer-term mechanically-induced changes in gene expression and cell/tissue remodelling. Several mechano-sensors of potential relevance for acute MEF responses have been identified. They include enzymes (e.g. mechano-sensitive kinases), structural elements from molecules (e.g. cytoskeletal and trans-membrane linkage-proteins) to membrane domains (e.g. caveolae) or more complex assemblies (e.g. contractile filament lattice and z-disks), but of particular interest are ion translocation mechanisms afforded by Mechanically Gated Channels (MGC).

MGC may serve both as sensors and as effectors of MEF responses. Embedded in membranes, they convert mechanical stimuli, putatively including in-plane membrane tension, membrane thickness and curvature, as well as matrix-protein interactions, into electrical and biochemical signals. MGC can affect, therefore, a wide range of cellular processes, with response times in the millisecond-domain relevant for acute cardiac MEF.

MGC were discovered in 1984 by the team of Frederick Sachs in embryonic chick skeletal myocytes. ${ }^{29}$ Four years later, William Craelius and co-workers published the first MGC recordings from mammalian cardiomyocytes. ${ }^{30}$ Since then, in addition to stretch-activated 
whole-cell currents, single-channel activity has been identified in a wide range of cardiac cells, ${ }^{31}$ including atrial myocytes, ${ }^{32}$ foetal $^{30}$ and (for potassium selective MGC at least) adult ventricular myocytes, ${ }^{33}$ as well as cardiac non-myocytes. ${ }^{27}$

In the 1990s, the first MGC was cloned from Escherichia coli (MscL (Mechano-sensitive channel of Large conductance), ${ }^{34}$ and the molecular nature of the first mammalian MGC reported. ${ }^{35}$ Since then, an increasing number of MGC has been identified and a large proportion of them are expressed and functional in the heart (Figure 1).

Since block of MGC in the mammalian heart can prevent certain forms of mechanicallyinduced heart rhythm disturbances in the experimental setting, ${ }^{36,37}$ they form a putative therapeutic target. This has motivated the present assessment of what we know about them so far.

\section{Channel Activation: Mechanical Modulation vs. Mechanical Gating}

Mechanically Modulated Ion Channels vs. Mechano-Gated Ion Channels-Ion channels, relevant for MEF, are characterised by their ability to change open probability in direct response to mechanical stimulation. Traditionally, mechanically gated ion channels have been classed according to the stimulus by which they were activated (e.g. cell volume activated channels, stretch activated channels; Figure 2). However, it is difficult to apply perturbations in a way that alters only one mechanical parameter, even if techniques for controlled mechanical stimulation of membrane patches have improved. ${ }^{38-40}$ In this paper, we refer to MGC as channels that can be activated by a mechanical stimulus alone. Channels that are normally activated by a different type of stimulus, but with a gain that is affected by the mechanical environment, or those that require co-activation by nonmechanical stimuli, will be referred to as Mechanically Modulated Channels (MMC).

An example of MMC are channels normally classed as voltage gated-These include potassium, ${ }^{41}$ calcium, ${ }^{42-44}$ and sodium ${ }^{45,}{ }^{4647}$ channels. Mechanical modulation of $\mathrm{Kv}$ channels $\left(\mathrm{K}^{+}\right.$channel, Voltage-gated) ranges from mechanically-induced redistribution (e.g. integration of Kv1.5 channels into the sarcolemma of rat atrial myocytes) ${ }^{48}$ to direct stretch-induced gating (e.g. of Kir channels [ $\mathrm{K}^{+}$inwardly-rectifying channel] in murine ventricular myocytes). ${ }^{49}$ Similarly, voltage-sensitive sodium channels can be affected by the mechanical environment (such as $\mathrm{Na}_{\mathrm{v}} 1.5\left[\mathrm{Na}^{+}\right.$channel, voltage-gated] in HEK [Human Embryonic Kidney] cells). ${ }^{50}$ Modification of the channel stability at the membrane is another type of modulation and has recently been exemplified for the L-type calcium channel: Polycystin-1, well-known to act as a mechanosensor in several cell types, can stabilise the entire pool of L-type channel proteins in rat cardiomyocytes. ${ }^{51}$

Mechanical modulation of voltage-sensitive channel gating is perhaps less surprising than often assumed, given that voltage sensing requires conformational rearrangements of the channel protein. ${ }^{52}$ If channel opening is associated with an increase in protein dimensions in the membrane plane, then the open state should be favoured by increased membrane tension. That said - the precise conformational changes of many ion channels are not known, and it is clear that not all channels are mechano-sensitive in standard experimental conditions (for example TASK channels). ${ }^{53}$ 
Ligand-activated MMC—GABAA (gamma-aminobutyric acid) and P2X (purinergic) receptors ( $\mathrm{P} 2 \mathrm{X}_{3}$ and $\mathrm{P} 2 \mathrm{X}_{4}$ subtypes in particular), are both expressed in the heart, though not in cardiomyocytes but in neurons and smooth muscle cells, respectively. ${ }^{54,55}$ They were suggested to participate in mechano-transduction processes, but their direct mechanosensitivity remains to be established. $\mathrm{P} 2 \mathrm{X}_{4}$ is not activated by shear stress alone, and their role in mechano-transduction is suggested to stem from the ATP release that can be mechanically induced by them, as shown in endothelial cells. ${ }^{56}$

Sarcolemmal $\mathbf{K}_{\text {ATP }}$ channels ( $\mathbf{K}^{+}$channel, ATP-inactivated), discovered in cardiac myocytes in the early $1980 \mathrm{~s},{ }^{57}$ are sensitive to their mechanical environment. ${ }^{58}$ These $\mathrm{K}_{\mathrm{ATP}}$ channels are hetero-octamers comprising two subunits: the pore-forming subunit with two membrane-spanning regions (Kir6.1 or Kir6.2 [ $\mathbf{K}^{+}$inwardly-rectifying channel]), and the regulatory subunit sulfonylurea receptor (SUR1, SUR2A, or SUR2B). ${ }^{59,}{ }^{60} \mathrm{~K}_{\mathrm{ATP}}$ are highly expressed in atrial and ventricular cardiomyocytes of murine models ${ }^{61,62}$ and in human heart. ${ }^{63}$

In normal metabolic conditions, $\mathrm{K}_{\mathrm{ATP}}$ channels are inactivated. If ATP levels fall, $\mathrm{K}_{\mathrm{ATP}}$ open probability increases. In the presence of stretch, this increase occurs at less reduced ATP levels. ${ }^{64}$ This may explain the difference between in vitro studies (where ATP levels have to be severely reduced to open $\mathrm{K}_{\mathrm{ATP}}$ ) and the in vivo setting (where stretch of cardiac tissue its present at all times, and presumably elevated in regions with reduced ATP). It is thought that $\mathrm{K}_{\mathrm{ATP}}$ channels are gated by local bilayer tension, and that this is affected by the cytoskeleton. ${ }^{65}$

$\mathrm{K}_{\mathrm{ATP}}$ channels may have a protective role in ischaemia. ${ }^{66}$ Interestingly, stretchpreconditioning, known to reduce ischaemia-reperfusion injury, is abolished by blocking $\mathrm{K}_{\mathrm{ATP}}$ channels. ${ }^{67}$ Of note, cardiac $\mathrm{K}_{\mathrm{ATP}}$ channels are also present and active in fibroblasts, suggesting that one must consider cardiac pre-/post-conditioning effects on cells other than just cardiomyocytes. ${ }^{68-70}$ As with other $\mathrm{K}^{+}$channels, $\mathrm{K}_{\mathrm{ATP}}$ opening favours re-/ hyperpolarization. While beneficial in preventing spurious excitation of resting cells, this also shortens the action potential (AP) duration (APD) and reduces the refractory period. The latter could help to establish an arrhythmogenic substrate and support re-entry.

\section{Channel Activation: Cell Volume vs. 'Stretch'}

\section{Cell Volume-Activated Channels (VAC) are generally regarded to be MGC-}

That said, their mechanism of activation in the heart is poorly understood. What is known is that increases in cell volume, whether by swelling ${ }^{71}$ or pipette-based cell inflation ${ }^{72}$, tend to activate chloride ${ }^{71}$ or potassium conductances. ${ }^{32}$ While cell volume changes undoubtedly cause mechanical deformation, VAC-activation tends to occur with significant lag-times (tens of seconds to minutes) after the onset of cell volume changes. ${ }^{73}$ This has put into question the role of direct mechanical stimuli as drivers of VAC gating, and it has been suggested that swelling-induced changes in cytoskeletal structures must take place before mechano-sensitive electrophysiological responses are seen. ${ }^{74}$

In terms of patho-physiological settings, cell swelling can be observed in ischaemia, particularly upon reperfusion, ${ }^{75}$ and VAC are understood to affect cardiac electrical 
behaviour in these conditions. Interestingly, VAC-like $\mathrm{Cl}^{-}$conductances are constitutively activated in hypertrophied cardiomyocytes, ${ }^{71}$ lending credence to the notion that structural aspects of cardiomyocyte organisation matter. Recently, LRRC8A (aka SWELL1), has been identified by two independent groups as an essential component of the ubiquitous volumeregulated anion channels VRAC. ${ }^{76,77}$ This discovery has been a result of genome-wide RNAi screens, and provided a new molecular candidate to better understand cell volume regulation.

At the same time, the normal cycle of cardiomyocyte contraction and relaxation is not generally assumed to be associated with pronounced changes in cell volume. This, and the lag-time for VAC activation, make it unlikely that these channels are main contributors to acute, beat-by-beat MEF (for more information on cardiac VAC, $\mathrm{see}^{71}$ ).

Stretch-Activated Channels (SAC) - 'the' quintessential MGC-SAC increase their open probability in direct response to membrane deformation. Evidence demonstrating that lipid bilayer forces are sufficient to gate SAC was obtained for several bacterial, fungal, ${ }^{78}$ and two vertebrate channels, TREK-1 (TWIK-related $\mathrm{K}^{+}$channel with TWIK standing for Tandem of two-pore $\mathrm{K}^{+}$domains in a weak inwardly rectifying $\mathrm{K}^{+}$channel) and TRAAK (TWIK-related arachidonic acid-activated $\mathrm{K}^{+}$channel). ${ }^{79,80}$ The small number of channels tested in this way is caused in part by technical difficulties to purify or produce functional channel reconstitutes in pure lipid bilayers. Also, several SAC are likely to require cytoskeletal and linker-proteins, ${ }^{81}$ and/or possibly soluble factors or messengers for activation. ${ }^{82}$ Interestingly, mutations in cytoskeletal proteins have been linked to cardiac pathologies, ${ }^{83-86}$ including rhythm disturbances, ${ }^{87,88}$ though thus far this would not appear to act via effects on MGC, but rather through effects on voltage-dependent channels and transporters that indirectly affect cardiac excitation-contraction-coupling. Several biophysical models have been proposed to address energetic interactions at the membraneprotein interface and contributions of lipid organization or, in addition to in-plane stress, changes such as membrane thinning have been suggested as relevant atomistic-level stimuli. ${ }^{89-91}$ These models, mainly obtained from bacterial channels reconstituted in liposomes, suggest that MGC can be gated by forces from lipids in the range of hundreds of $\mathrm{pN}$ (220 $\mathrm{pN}$ for MscL for example).$^{92}$ More broadly, including eukaryotic channels in the cellular context (i.e. in the presence of the cytoskeleton), it appears that MGC are sensitive to a wide range of force intensities characteristic for living cells, from 2 to $10 \mathrm{mN} / \mathrm{m}$ (data acquired on cultured cells). ${ }^{93,} 94$ To understand the mechanical gating of SAC, structural data is needed. So far, the structure of the bacterial MscL ${ }^{95}$ and MscS (Mechano-sensitive channel of Small conductance), ${ }^{96,97}$ as well as of mammalian TRAAK ${ }^{98}$, Piezo $^{99}$ and BK $\left(\mathrm{Big} \mathrm{K}^{+}\right)^{100}$ channels has been resolved at atomic resolution.

\section{Channel Location: Sarcolemmal vs. Non-Sarcolemmal}

Sarcolemmal MGC-Single channel patch clamp investigations require direct access of the pipette tip to the membrane containing channels, such as MGC. As the outer surface of the sarcolemma is easily accessible, it is the membrane from which most electrophysiological MGC data have been reported, so much so, that the notion of MGC seems synonymous with 'sarcolemmal ion channel'. However, not all sarcolemmal channels 
are present at the accessible cell surface, as 'hidden' cell surface membrane, such as in Ttubules (T-tub) and caveolae, contains ion channels. ${ }^{101}$ In addition, MGC are present also on endo-membranes of organisms such as plants ${ }^{102}$ and yeast, ${ }^{103}$ and there is evidence to suggest that the same may hold true for mammalian heart cells. ${ }^{21,} 104$ Apart from BK channels, which appear in a range of endo-membranes and whose mechano-gating is discussed controversially (see section on BK channels, below), the following MGC are interesting examples that warrant further investigation.

Non-Sarcolemmal MGC: Sarcoplasmic Reticulum (SR)—Calcium handling in cardiac cells is mechano-sensitive, involving mechanisms from changes in $\mathrm{Ca}^{2+}$ buffering and troponin-C binding, to $\mathrm{Ca}^{2+}$ fluxes. ${ }^{105,106}$ This includes $\mathrm{Ca}^{2+}$ releasability from the SR, such as evident in an increased frequency of $\mathrm{SR} \mathrm{Ca}^{2+}$ release events (sparks) upon acute mechanical stimulation, whether using axial cell stretch or local application of fluid 'puffs' to deform isolated cells. ${ }^{21,104}$ Mechanisms underlying the stretch-induced increase in spark rate continue to be investigated and may include mechanical modulation of RyR (Ryanodine Receptor) $\mathrm{Ca}^{2+}$ release channels of the SR.

This could have functional relevance not only for priming $\mathrm{SR} \mathrm{Ca}^{2+}$ release and/or terminating it upon successful cell shortening, but it would also have the potential of affecting cardiac electrophysiology. If stretch triggered $\mathrm{Ca}^{2+}$ release from the SR, this could affect trans-sarcolemmal $\mathrm{Na}^{+} / \mathrm{Ca}^{2+}$ exchange and - in particular in cells that are already $\mathrm{Ca}^{2+}$ overloaded (e.g. in ischaemic conditions) - trigger ectopic excitation. ${ }^{34}$

Non-Sarcolemmal MGC: Other Organelles-Mitochondrial $\mathrm{K}_{\mathrm{ATP}}$ channels contribute to ischemic pre- ${ }^{107}$ and post-conditioning, ${ }^{108,} 109$ potentially protecting cells by maintaining ATP production during hypoxic episodes. ${ }^{110}$ While the molecular identity of the cardiac mitochondrial $\mathrm{K}_{\mathrm{ATP}}$ is still debated, it is possible that it shares mechanical modulation with its sarcolemmal counterpart (discussed in section "Ligand-activated MMC").

The nuclear envelope shows significant deformation during application of mechanical forces to a cell. ${ }^{111-113}$ Nuclear mechano-sensing is an under-appreciated research area with significant importance for the understanding of mechanically induced changes in cell behaviour. ${ }^{114}$ In terms of ion channels, TRPV4 (Transient Receptor Potential Vanilloid 4) was localised in cultured neonatal rat ventricular myocytes in the nucleus only, ${ }^{115}$ though functional data confirming actual ion channel activity of this protein are still outstanding.

Of course, for MEF to affect heart rhythm, trans-membrane potential changes must occur, and the focus on sarcolemmal MGC is therefore not merely a consequence of conceptual restrictions or technical constraints (in terms of channel accessibility by recording tools), but related to the focus on functional responses of interest and, thus, the topic of this review.

Beyond Cardiomyocytes-Another potentially questionable preconception is that the normal heart consists chiefly of cardiomyocytes. While true in terms of volume fraction, non-myocytes such as endothelial and interstitial cells outnumber muscle cells in the heart. Endothelial cells of the cardiovascular system possess MGC, ${ }^{116-118}$ and so do 
fibroblasts. ${ }^{19-121}$ While presumably required for functions such as shear sensing and directional extracellular matrix protein deposition in response to mechanical clues, ${ }^{122}$ ion channels in non-myocytes may affect cardiac electrophysiology in the presence of heterotypic cell coupling in the heart. Such coupling appears to exist in native myocardium, both in normal ${ }^{123-125}$ and fibrotic/scarred tissue, ${ }^{126,127}$ as reviewed in detail elsewhere. ${ }^{128}$

\section{Cardiac SAC: Molecular Candidates}

\section{Criteria and Terminology}

Knowledge about molecular candidates for cardiac MGC has seen significant improvements over the past decade. Candidate proteins and protein families have emerged, and new, often complex regulatory contributions have been proposed. At the same time, specific information about mechano-transduction pathways remains relatively limited. To address present controversies, Johanna Arnadottir and Martin Chalfie ${ }^{129}$ suggested four criteria to establish whether or not a protein forms an ion channel that transduces mechanical forces and is relevant for organ function. 1: the protein must be expressed and localised in the mechanosensory organ. 2: the channel is required for mechano-sensitive responses, but not merely for normal development of the mechano-receptor cell or signalling downstream of the stimulus. 3: alteration of channel properties (conductance, kinetics, sensitivity, selectivity) alter the properties of mechanical responses. 4: the channel should be gated mechanically in heterologous expression system. In the mammalian heart, proteins have not generally been assessed as yet for these four criteria, highlighting avenues for further investigation.

In this review, $\mathrm{SAC}$ are sub-divided by their ion selectivity into $\mathrm{K}^{+}$-selective $\left(\mathrm{SAC}_{\mathrm{K}}\right)$ and cation non-selective channels $\left(\mathrm{SAC}_{\mathrm{NS}}\right)$.

\section{$\mathrm{SAC}_{\mathrm{K}}$}

Donghee Kim et al. described first whole-cell $\mathrm{SAC}_{\mathrm{K}}$ currents ( $\mathrm{I}_{\mathrm{SAC}, \mathrm{K}}$ ) in cardiac cells. ${ }^{32}$ $\mathrm{SAC}_{\mathrm{K}}$, are outwardly rectifying, allowing potassium ions to move more easily out of the cell than into it. They have large single channel conductances and inactivate in a time-dependent manner. Their activation causes membrane re- or hyperpolarization. ${ }^{64}$ Single-channel recordings of $\mathrm{I}_{\mathrm{SAC}, \mathrm{K}}$ in adult mammalian cardiac myocytes have been obtained from atrial ${ }^{32}$ and ventricular myocytes. ${ }^{33,130,131} \mathrm{I}_{\mathrm{SAC}, \mathrm{K}}$ is thought to be carried by $\mathrm{K}_{2 \mathrm{P}}\left(\mathrm{K}^{+}\right.$, two Pdomain) ${ }^{*}$ channels expressed in the mammalian heart. ${ }^{132}$ The most studied among them is TREK-1.

TREK-1 is active over a range of physiological membrane voltages. Channel gating is polymodal, activated by an impressive number of stimuli including intra- and extracellular $\mathrm{pH}$, temperature, fatty acids, anaesthetics and, crucially, membrane deformation (curvature) or stretch. ${ }^{133}$

\footnotetext{
${ }^{*} \mathrm{~K}+$ channels with two $\mathrm{P}$ domains. A P domain is a short amino acid segment between two transmembrane helices that contributes to formation of the inner part of the pore, acting as a selectivity filter.
} 
TREK-1 expression appears distinctly heterogeneous in the heart, with a gradient of mRNA expression that increases transmurally, from sub-epicardial to sub-endocardial myocytes. ${ }^{134,135}$ This heterogeneity appears to correlate with transmural changes in MEF sensitivity, whereas stretch causes the most pronounced AP shortening in the subendocardium. ${ }^{136,137}$ However, while TREK-1 mRNA expression was observed in murine atria and ventricles, ${ }^{132,134,138,139}$ it has not, to our knowledge, been found the human heart. ${ }^{140,141}$ That said, whole-tissue mRNA, and even protein assays, are not necessarily true reflections of presence, let alone relevance, of a target, which may derive importance from high expression in a minority cell population (cardiac Purkinje fibres would be an example).

Where observed, TREK-1 protein appears to be arranged in longitudinal stripes on the surface of cardiomyocytes: a pattern that could support directional stretch sensing. ${ }^{131}$ Whole cell currents exhibiting the characteristics of recombinant TREK-1 (including sensitivity to volatile anaesthetics, arachidonic acid, $\mathrm{pH}$, internal acidification, and stretch) have been observed in atrial and ventricular myocytes of several species including rat, mouse and pig. ${ }^{137,} 142$

In terms of functional relevance, TREK-1 contributes to the 'leak' potassium conductance in cardiomyocytes. ${ }^{137,143}$ As such, it aids normal repolarization and diastolic stability. However, increased TREK-1 current, for example during stretch, could shorten APD to a degree where this becomes pro-arrhythmic. ${ }^{136}$ In keeping with this, several well-established anti-arrhythmic drugs, including lidocaine, mexiletine, propafenone, carvedilol, dronedarone, and vernakalant, inhibit TREK-1. ${ }^{142}$

TREK-2 shares functional similarity with TREK-1, though little is known about its functional relevance in the heart. It appears active in chicken embryonic atrial myocytes, ${ }^{144}$ and it is expressed in rat atria. ${ }^{132}$

TRAAK is a TREK-1 homologue with similar biophysical properties and regulation, ${ }^{145}$ expressed in the human heart ${ }^{132}, 146$ TRAAK might form a human TREK-1 homologue, but its specific functional relevance in the heart is not yet known.

The similarity of electrophysiological properties of TREK-1, TREK-2 and TRAAK, and the overwhelmingly high expression levels of TREK-1 in murine model systems, may explain the paucity of experimental data on TREK-2 and TRAAK function. It is possible to differentially study them, as volatile anaesthetics activate TREK-1 and -2, but not TRAAK, ${ }^{147}$ while extracellular acidification inhibits TREK-1 but activates TREK-2. ${ }^{148}$ Detailed characterisation of the functional relevance of these MGC in mammalian heart in general, and in human tissue in particular, is a pre-requirement for consideration of their patho-physiological relevance and therapeutic target potential. This has, by and large, yet to occur.

BK channel activation is polymodal for a range of gating stimuli, which has given rise to different names for the same type of ion channel in a variety of studies (e.g. $\mathrm{SAK}_{\mathrm{CA}}, \mathrm{BK}_{\mathrm{Ca}}$ Alpha, SLO1, MaxiK). ${ }^{149}$ They are present in a number of cell and tissue types, including vascular smooth muscle, atrium and ventricles. ${ }^{150} \mathrm{BK}$ channels are found not only in the 
sarcolemma, but also in membranes of the endoplasmic reticulum, the Golgi apparatus, and mitochondria. ${ }^{149}$

Mechano-sensitivity of BK channels was established in membrane patches excised from cultured embryonic chick ventricular myocytes. ${ }^{151}$ However, as BK channels are activated by voltage changes and by alterations in intracellular $\mathrm{Ca}^{2+}$ concentration, ${ }^{150}$ it has been suggested that their mechano-sensitivity is indirect, occurring secondary to stretch-induced changes in intracellular $\mathrm{Ca}^{2+}$ concentration. ${ }^{152}$

As implied by their name, BK channels have large conductances. They have been suggested to contribute to heart rate control ${ }^{153}$ and to offer cardioprotection during ischaemia. ${ }^{154}$ Genetic variants of BK have been related with increased severity of systolic and general hypertension, as well as increased risk of myocardial infarction. ${ }^{155}$

\section{SAC $_{\mathrm{NS}}$}

Following on from the discovery of Sachs et al. of stretch-activated ion currents in avian skeletal muscle, ${ }^{29}$ Craelius et al. identified SAC whole-cell currents in mammalian heart muscle. This current had the typical linear current-voltage relationship of weakly-selective ion channels, which we now attribute to $\mathrm{SAC}_{\mathrm{NS}}\left(\mathrm{I}_{\mathrm{SAC}, \mathrm{NS}}\right){ }^{30}$ In contrast to $\mathrm{SAC}_{\mathrm{K}}, \mathrm{SAC}_{\mathrm{NS}}$ have smaller conductances and a reversal potential closer to zero $\mathrm{mV}$. With the reversal potential being positive to the resting potential of working cardiomyocytes, activation of $\mathrm{SAC}_{\mathrm{NS}}$ will depolarise resting heart muscle cells, potentially triggering premature or ectopic excitation. ${ }^{64}$

In contrast to $\mathrm{SAK}_{\mathrm{K}}$, no $\mathrm{SAC}_{\mathrm{NS}}$ single-channel recordings have been obtained from freshlyisolated adult ventricular cardiomyocytes. This has led to the suggestion that $\mathrm{SAC}_{\mathrm{NS}}$ may be hidden from patch pipette access, in membrane regions such as T-tub, ${ }^{156}$ caveolae, or at intercalated discs. ${ }^{157} \mathrm{~A}$ recent report suggests that a1A adrenergic-agonists may cause translocation of a putative $\mathrm{SAC}_{\mathrm{NS}}$ (TRPC6) from T-tub to the sarcolemma. ${ }^{158}$ Whether this occurs physiologically, and the extent to which this might serve as a useful experimental intervention to facilitate single-channel recordings of TRPC6 in adult ventricular myocytes, remains to be explored.

The main molecular candidates for $\mathrm{SAC}_{\mathrm{NS}}$ are Piezo and TRP channels.

Piezo1 and 2-The discovery of Piezo1 and Piezo2 by Ardem Patapoutian's group in 2010 represents a breakthrough in the field of mechano-transduction. ${ }^{40}$ Piezo proteins form true SAC, meeting the four criteria listed above. Stretch-activation was demonstrated by

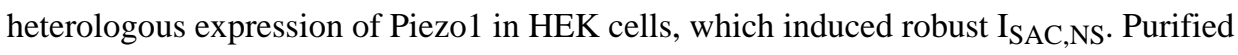
Piezo1, reconstituted into asymmetric bilayers and liposomes, forms ruthenium-red (a wellestablished pore blocker) sensitive ion channels, demonstrating that Piezo1 proteins are a pore-forming subunit of the channel. ${ }^{159}$ Further investigation is required to clarify whether Piezo1 ion channel subunits are intrinsically mechano-sensitive.

Currently, no functional data have been published on Piezo1 or Piezo 2 in the heart. However, as Piezo channel properties are similar to those of endogenous cardiac $\mathrm{SAC}_{\mathrm{NS}}$, 
including (weak) voltage dependency, single channel conductance, inactivation, and sensitivity to GsMTx-4 (Grammostola spatulata Mechano-Toxin 4), ${ }^{160}$ it is tempting to think that Piezo contributes to cardiac MEF. ${ }^{161}$

In terms of mRNA expression, Piezo1 has been observed in murine heart, ${ }^{40}$ albeit at low levels in comparison to expression in lung, bladder or skin. However, mRNA or protein expression in tissue should be interpreted with caution. The two do not necessarily correlate to one another, ${ }^{162}$ and even if protein expression is confirmed, it does not necessarily prove the presence of functional ion channels. Vice versa, low expression levels do not rule out functional relevance of a protein, in particular if it is present in a minority cell population (such as Purkinje fibres, whose mechano-sensitivity was subject of the paper that coined the term 'cardiac MEF'). ${ }^{10}$

This is an exciting and area of dynamic development. Basic science questions concerning structure, protein partners, and regulation of Piezo channels need to be addressed, as does the question of whether they are present in, and relevant for, the human heart.

TRP CHANNELS-Most mammalian TRP channels act as nonselective cation channels, passing $\mathrm{Na}^{+}, \mathrm{K}^{+}$, and in some cases $\mathrm{Ca}^{2+}$. They are widely expressed, involved in a variety of cell functions, and characterised by polymodal regulation. ${ }^{163}$ While the presence and extent of direct stretch activation of these channels has remained controversial, results from heterologous expression systems suggest that some TRP are good $\mathrm{SAC}_{\mathrm{NS}}$ candidates.

TRPC6 stretch-activation was characterised in HEK cells ${ }^{164}$ but was not confirmed in CHO and COS cells. ${ }^{82}$ It has been suggested that TRPC6 require the angiotensin II type 1 receptor to be mechano-sensitive. ${ }^{163,165}$ TRPC6 is among a small number of SAC candidates that are highly expressed in human heart homogenates. ${ }^{166}$ In mouse heart, TRPC6 appears localised in T-tub and, in agreement with this observation, de-tubulation inhibits I $_{S A C, N S}$ in murine ventricular cardiomyocytes. ${ }^{49}$ Whole-cell patch clamp experiments on mouse cardiomyocytes identified robust $\mathrm{I}_{\mathrm{SAC}, \mathrm{NS}}$ in response to shear stimuli, which was inhibited by pore-blocking TRPC6 antibodies. ${ }^{49}$ Murine TRPC6 knockout models suggest that the channel contributes to the slow force response, and may be involved in Duchenne muscular dystrophy, ${ }^{167}$ highlighting the potential clinical relevance of TRPC6 manipulation. In nonmyocytes, TRPC6 is proposed to promote myofibroblast transdifferentiation and it could act as a positive regulator in wound healing. ${ }^{168}$ Putative roles, both in myocytes and nonmyocytes, make this channel an interesting target for therapeutic intervention.

TRPC1 mechano-sensitivity is also discussed controversially. Stretch-activation of TRPC1 was first shown in Xenopus oocytes, ${ }^{169}$ but has not been confirmed in other expression systems. ${ }^{82}$ Like TRPC6, this channel is likely to require the presence of a partner protein. Caveolin1 has been reported to be a trafficking regulator of TRPC1. ${ }^{170,171}$ As caveolae are highly dynamic membrane regions, whose sarcolemmal integration is dynamically modulated by acute and sustained stretch, ${ }^{172,173}$ this observation points to the possibility that TRPC1 is mechano-modulated but not mechano-gated. 
TRPC3 protein has been identified in rat ventricular myocytes, where it is located in Ttubules. ${ }^{174}$ In mouse neonatal cardiomyocytes, this channel is involved in ROS (Reactive Oxygen Species) production in response to mechanical stimulation or to perfusion of OAG (1-oleoyl-2-acetyl-sn-glycerol), a non-specific activator of MGC. ${ }^{174}$ Recently, TRPC3/4 and 6 channels have been shown to contribute to pathological structural and functional remodelling after myocardial infarction. ${ }^{175}$ Blocking these channels is suggested to reduce pathological remodelling and to improve contractility, making TRPC channels new therapeutic targets in the context of post-myocardial infarction.

TRPV2 is expressed in mouse heart ${ }^{157,176}$ and has been reported to be activated by both cell-volume changes and patch pipette suction. ${ }^{177}$ Using the TRPV2 agonist probenicid in wild-type and TRPV2 constitutive knockout mice, it was proposed that this channel contributes to baseline function of the cardiac calcium-handling machinery. ${ }^{176}$ Like TRPC6, TRPV2 combines this putative physiological role with potential contributions to dystrophic cardiomyopathies in pathological settings. TRPV2 is overexpressed in dystrophic cardiomyocytes and contributes to $\mathrm{Ca}^{2+}$ influx. Interestingly, in cardiomyocytes challenged by osmotic shock, TRPV2 trafficking is impaired, leading to an accumulation of the protein on the sarcolemma and along T-tub, instead of their normal preferred location in the membranes of internal $\mathrm{Ca}^{2+}$ stores. ${ }^{178}$

TRPM4 (Melastatin TRP channel 4) is expressed in cardiomyocytes of several species including mouse, rat, and human. ${ }^{165}$ It has been implicated in stretch-activated responses of vascular smooth muscle. ${ }^{179}$ Overexpression of TRPM4 may be involved in an inheritable form of progressive familial heart block type I, ${ }^{67}$ though perhaps via mechanisms not directly related to TRPM4 mechano-sensitivity. Its physiological role in the heart is currently unknown.

TRPP2 (Polycystin TRP channel) is primarily found on the endoplasmic/sarcoplasmic reticulum and in primary cilia. ${ }^{180}$ However, a TRPP2-like protein appears to function as a channel in the plasma membrane of rat ventricular cardiomyocytes, ${ }^{181}$ acting as a modulator of the cardiac ryanodine receptor, RyR2. ${ }^{182}$ Given its contribution to intracellular calcium cycling, TRPV2 dysregulation has been suggested to be involved in the development of heart failure. ${ }^{183}$

\section{Pharmacological Modulators}

The best-known pharmacological tools to alter SAC activity are blockers of limited specificity, including gadolinium ions, amiloride, and cationic antibiotics (streptomycin, penicillin, kanamycin). Caution is needed, in this context, when interpreting research on stretch-effects in cultured cells, as standard media contain antibiotics that may alter (reduce) background availability of SAC.

In spite of their limited selectivity, the above SAC-blockers have been highly productive for experimental cell research, as reviewed elsewhere. ${ }^{93,184}$ Their utility in whole animal or human studies is limited though. Thus, gadolinium is chelated almost completely in solutions that contain physiological pH-buffer systems, ${ }^{185}$ while clinically used compounds (amiloride, antibiotics) exert their effect primarily and predominantly via their established 
pharmacological targets, rather than possible (side-)effects on SAC. Also, not always is in vitro behaviour indicative of in situ response patterns. Thus, streptomycin's ability to block stretch-responses in isolated cells ${ }^{185}$ is not necessarily preserved over the same concentration ranges and response times in native tissue, ${ }^{186}$ highlighting the possibility of false-negative findings on SAC-contributions probed using the antibiotic in more integrative model systems.

A number of other clinically-applied compounds affect molecular SAC candidates with a relatively narrow spectrum of action. TREK-1 activity, for example, is modulated by the neuroprotective agent riluzole $(10-100 \mu \mathrm{M})$, the antidepressant fluoxetine (Prozac; IC50 10 $\mu \mathrm{M}$ ), and millimolar concentrations of volatile halogenated and gaseous general anesthetics, ${ }^{145}$ in the case of channel activation with the potential for unexpected falsepositive effects in studies on anaesthetised mammals.

Among the few specific SAC inhibitors identified is the peptide GsMTx- $4,{ }^{160}$ isolated by Sachs et al. from a Chilean tarantula venom. ${ }^{187}$ In contrast to $\mathrm{SAC}_{\mathrm{K}}, \mathrm{SAC}_{\mathrm{NS}}$ are distinctly sensitive to this peptide, though the mechanism of this specificity is unknown. GsMTx-4 inhibits TRPC 5, ${ }^{73}, 188$ TRPC6, ${ }^{164}, 189$ and Piezo1 channels, when applied to the external membrane. ${ }^{190,191}$ Both the D and L enantiomers of GsMTx-4 block SAC $\mathrm{NS}_{\mathrm{NS}}$, showing that the mechanism of action is not stereospecific or chiral. ${ }^{192}$ Instead, the mode of action of GsMTx-4 is thought to involve insertion into the outer membrane leaflet (GsMTx-4 is an amphipath) in the proximity of the channel, relieving lipid stress sensed by the channel and favouring the closed state of SAC. ${ }^{192}$ Counterintuitively, GsMTx-4 sensitizes bacterial MscS and MscL to increased tension, ${ }^{193}$ while it has no effect on TREK-1. ${ }^{190}$ The mode of action of GsMTx-4 on SAC requires further elucidation.

A $\mathrm{SAC}_{\mathrm{K}}$ specific blocker is Spadin. It inhibits TREK-1 mechano-gating, ${ }^{194}$ without affecting TREK-2 and TRAAK. ${ }^{194}$ Additional TREK-1 modulators, including activators, have recently been identified by Sviatoslav Bagriantsev et al, ${ }^{195}$ and the utility of these compounds for cardiac MEF research awaits exploration. Cardiac potassium-selective MMC that have been probed using specific inhibitors include $\mathrm{K}_{\mathrm{ATP}}$ channels. The mitochondrial $\mathrm{K}_{\mathrm{ATP}}$ is inhibited by the 5-hydroxydecanoate (5-HD), while HMR-1098 has been identified as an antagonist for the sarcolemmal $\mathrm{K}_{\mathrm{ATP}} \cdot{ }^{110,196}$ Glibenclamide is also a popular pharmacological tool, inhibiting sarcolemmal $\mathrm{K}_{\mathrm{ATP}}$ from either side of the membrane. ${ }^{197}$

Concerning TRP channels, TRPC6 antibodies have been used as specific inhibitors of stretch-responses in isolated cells. ${ }^{49}$ More generally, TRPC6 is modulated by hyperforin, 198 TRPV1 by capsaicin, ${ }^{199}$ TRPV2 by probenicid, ${ }^{200}$ and TRPM4 by 9-phenanthrol. ${ }^{201}$

If specific inhibitors are rare, even fewer specific activators have been identified. Recently, Yoda1 has been shown to be an agonist for both human and mouse Piezo1, affecting sensitivity and inactivation kinetics of the channel. This compound does not act via protein partners of the channel as it is still efficient in artificial bilayers. ${ }^{202}$ If confirmed in native heart tissue, it would represent a powerful tool to investigate Piezol functions in integrated systems, especially if the channel was closed in physiological conditions. 
The potential for MGC and MMC modulators as pharmacological tools in heart rhythm management has been expertly reviewed by Ed White. ${ }^{106}$ Considering the ubiquitous presence of these channels in all cell types of the human body, pharmacological interventions targeting a specific organ are challenging, requiring selective delivery and avoidance of side-effects on other body functions. A possibility here is genetic targeting, with the potential of not only aiming for a specific organ, but for a specific cell type in that organ (cardiomyocytes, endothelial, interstitial or immune cells, etc.) or a defined disease progression stage. Again, this is a domain of research requiring additional effort/focus.

\section{Mechanistic Projection Between Levels of Investigation}

The heart generates, experiences, and responds to a highly dynamic mechanical environment. Parameters relevant for cardiac mechano-reception change dynamically and on a range of different time scales, from years (e.g. ontogenesis, disease development, or aging) to fluctuations that are circadian (e.g. physical activity), spread over tens of seconds (e.g. respiratory cycle induced alternations in venous return), or happen in milliseconds (e.g. mechanical activation during a heartbeat). MGC are, jointly with photo-transduction systems, among the most rapid sensors in biological systems, though they may make contributions over the whole range of time scales mentioned above.

Knowledge about SAC-contributions to chronic cardiac conditions is limited, although they have been implicated in the development of cardiac hypertrophy and heart failure. ${ }^{203-205}$ Identification of causal chains of events is difficult in chronic disease, as a host of relevant parameters, from tissue and cell visco-elastic properties to ion channel expression, ${ }^{206}$ remodel.

Projection from SAC activity to cell and tissue levels during acute stretch-induced changes in cardiac electrophysiology is more straightforward. Activation of $\mathrm{SAC}_{\mathrm{K}}$, with their reversal potential negative to the resting membrane potential of cardiac cells, will tend to hyperpolarize resting cells. $\mathrm{SAC}_{\mathrm{NS}}$, in contrast, with reversal potentials typically between 0 and $-20 \mathrm{mV}$ in cardiac cells, will in turn depolarize resting cells, if sufficient current flow is generated. ${ }^{207}$ Interestingly, all stretch-induced changes in resting membrane potential of cardiac myocytes reported so far involved depolarization, up to and including mechanical induction of AP. ${ }^{15}$ Resting membrane depolarization can be explained by $\mathrm{SAC}_{\mathrm{NS}}$, but not by $\mathrm{SAC}_{\mathrm{K}}$, suggesting that the latter do not normally determine acute electrophysiological response patterns of the heart to diastolic mechanical stimulation.

Matters get more complicated during the AP, when timing of mechanical stimuli warrants closer examination. While $\mathrm{SAC}_{\mathrm{K}}$ activation would continue to have a re- or hyperpolarizing effect, $S_{A C}$ will do so only while membrane potential levels are positive to the $S_{A C}$ reversal potential. As a consequence, $\mathrm{SAC}_{\mathrm{NS}}$ activation will shorten $\mathrm{APD}$ during early repolarization but may, if sustained or applied late in the AP, give rise to late AP prolongation, or even after-depolarization-like events (Figure 3). Indeed, both early and late stretch-induced after-depolarization-like behaviour have been reported in cardiac research. ${ }^{64}$ If supra-threshold, these may mechanically trigger ectopic excitation. ${ }^{208}$ 
Timing-dependence of stretch effects on cellular electrophysiology matters also for the projection from cell to organ/organism levels, as both electrical activation and repolarization are characterised by a wave-like behaviour across the heart. This means that the ECG offers an inherently limited temporal reference for characterization of local events, as illustrated in more detail in section 5 .

Quantitative projection from molecule to organism, including elucidation of spatio-temporal modulators of stretch responses, has benefitted from computational modelling. ${ }^{209-211}$

Interestingly, the vast majority of observed acute electrophysiological responses of the heart to stretch can be successfully reproduced simply by invoking $\mathrm{SAC}_{\mathrm{NS}} .{ }^{212}$

Of course, computational demonstration of quantitative plausibility is neither proof nor replacement of experimental validation. Occasionally, such validation trails computational predictions by a decade or more. An example are models of impact-induced arrhythmogenesis (aka Commotio cordis [CC], agitation of the heart, without structural damage), ${ }^{3,4}$ which - using $2 \mathrm{D}^{213}$ and $3 \mathrm{D}^{214}$ simulations - concluded that the rare but devastating CC-induced ventricular fibrillation (VF) requires spatio-temporal overlap of mechanically-affected tissue with the trailing edge of the repolarization wave. This has now been confirmed experimentally (see also section 5). ${ }^{215}$

Among the present challenges in projecting from protein to pathology is the difficulty of assessing and comparing actual effective mechanical parameters of ion channel stimulation. Few studies have quantified the stretch imparted upon patch-clamped membranes during SAC investigations. ${ }^{216}$ At the cell and tissue level, cell or sarcomere length (SL) are used as a read-out of strain, ${ }^{217}$ and occasionally as an input parameter to gauge mechanical modulation of cardiomyocytes. ${ }^{24,} 218$ In native heart, implanted ultrasonic transducers, ${ }^{219}$ echo and $\mathrm{MRI}^{220}$ have all been applied to characterise transmural deformation patterns. But, and this is a crucial limitation: none of these techniques allows one to actually measure stress/force inside the preparation (whether a membrane patch, a cell, or a tissue/organ). An exciting development here is the advent of fluorescent force reporters, ${ }^{221}$ whose application to cardiac MEF research could revolutionise concepts and understanding of cardiac mechano-sensitivity.

\section{Clinical Relevance}

In terms of physiological beat-by-beat effects, activation of SAC has been shown to underlie the non-neural component of the stretch-induced increase in spontaneous sino-atrial node (SAN) cell pacemaking rate, aka the Bainbridge effect. ${ }^{20}$ Block of SAC using GsMTx-4 (but not using streptomycin, see section 3) terminates this positive chronotropic response in native SAN tissue explants ${ }^{186}$ which, in its guise of a respiratory sinus arrhythmia, persists at whole body level - even in heart transplant recipients and/or after additional pharmacological denervation. ${ }^{222}$

Surprisingly, this is about all we know for sure regarding the physiological relevance of $\mathrm{SAC}$ in heart rate and rhythm regulation. 
It is possible, perhaps probable, that the key role of cardiac SAC under normal conditions is related to auto-regulation of contractile behaviour. This could occur via stretch-dependent adjustment of trans-sarcolemmal $\mathrm{Ca}^{2+}$ influx, ${ }^{223}$ preservation of intra-cellular $\mathrm{Ca}^{2+}$ secondary to stretch-induced trans-sarcolemmal influx of $\mathrm{Na}^{+}, 152,224$ and/or stretchmodulated grading of $\mathrm{Ca}^{2+}$ release from the SR. ${ }^{21}$ Any or all of these mechanisms could contribute to both acute (Frank-Starling response) ${ }^{225}$ and sustained (slow force response) ${ }^{226}$ adjustments of cardiac contractility to changes in the heart's mechanical environment (highly relevant for contractile cells in the heart, given that they are not controlled via neuromuscular junctions, such as is the case in skeletal muscle), while their effects on cardiac electrophysiology would be 'secondary'.

In contrast, SAC have been implicated in a host of clinically relevant scenarios, from acute arrhythmogenesis, to sustenance and termination of arrhythmias, as explored next.

\section{Mechanical Induction of Arrhythmias (Acute)}

As mentioned before, stretch of resting myocardium, if strong enough to cause any change in membrane potential, gives rise to depolarization, potentially triggering ectopic excitation. In human volunteers, this has been shown to occur upon external mechanical energy delivery such as by precordial tapping, at energy levels as low as $0.04 \mathrm{~J}$ (equivalent to dropping a golf ball [46 g] from a height of $9 \mathrm{~cm}$ ). ${ }^{227,} 228$ Mechanically-induced ectopy is a common adjunct to intra-cardiac device-tissue interactions such as during cardiac catheterization, ${ }^{229}$ and it may even be triggered by the heart's own mechanical activity, such as upon acute obstruction of ventricular outflow during balloon valvuloplasty. ${ }^{230}$

Mechanically-induced ectopy is usually benign, but in the context of pre-existing pathologies, it may give rise to sustained tachyarrhythmias. In a porcine model of pathologically prolonged QT-intervals, for example, $\beta$-adrenergic stimulation by bolusinjection of isoproterenol can give rise to ventricular after-contractions, originating from near-endocardial locations. These after-contractions precede early after-depolarization-like behaviour in near-epicardial tissue. Upon reaching threshold for induction of ectopic excitation, this can initiate torsades de pointes. ${ }^{231}$

Much rarer than mechanically induced ectopy, but more widely known, is CC, in particular in its most severe form of CC-induced VF. Here, a mechanical impact to the precordium, usually by a projectile such as an ice hockey puck or baseball, gives rise to acute MEF responses that - during a very narrow critical window of about $20 \mathrm{~ms}$ - can cause instantaneous induction of VF. ${ }^{232}$ The mechanisms underlying VF induction are discussed controversially, with focus either on abnormal repolarization ${ }^{233}$ or on abnormal excitation overlapping the trailing edge of normal repolarization. ${ }^{3}$ Also, the role of the impactassociated surge in intra-ventricular pressure is subject of debate, while it is accepted that local mechanically-induced ectopy occurs in myocardium nearest to the site of mechanical stimulation, both in isolated heart ${ }^{215,234}$ and whole animal. ${ }^{234}$

Recent optical mapping studies of isolated heart models of $\mathrm{CC}$ have confirmed that $\mathrm{SAC}_{\mathrm{NS}}$ are involved in the generation of ectopic excitation, and that deterioration into VF is seen only if ectopy occurs right on the edge of the preceding normal repolarization wave..$^{215}$ This 
confirms prior modelling-based predictions ${ }^{213}$ and sheds further light on the unusually narrow critical window for mechanical induction of VF in whole animal studies: the precondition for overlap of mechanical stimulus and trailing repolarization edge is met for any specific pre-cordial impact location for a brief part of the ECG cycle only (if one could mechanically stimulate other parts of the heart by extracorporeal impact, the accompanying critical time window would be shifted). Thus, the critical window for VF-induction during $\mathrm{CC}$ exists in time and in space, reconfirming that systemic (ECG) and local (AP) timings are not interchangeable.

\section{Mechanical Sustenance of Arrhythmias (Chronic)}

Mechanical contributions to chronic arrhythmias have been implicated in the perpetuation of both atrial ${ }^{235-237}$ and ventricular tachycardias. ${ }^{238}$ Mechanisms here may range from activation of SAC that alter APD, ${ }^{239}$ slow conduction velocity, ${ }^{173,235,238}$ or increase dispersion of repolarization, ${ }^{238}$ over changes in expression of mechanically modulated ion channels ${ }^{206}$ and alterations in connexin phosphorylation, ${ }^{240}$ through to remodelling of tissue architecture, composition, ${ }^{241}$ and innervation. ${ }^{242}$

Given the multiplicity of mechanisms and pathways involved, and the variable time scales over which they manifest themselves, this area is understudied, in particular with regard to ventricular arrhythmogenesis. A conceptually interesting approach to probing effects of sustained ventricular stretch in cardiac arrhythmogenesis has been employed by Menashe Waxmann et al. ${ }^{243}$ who used the Valsalva manoeuvre to temporarily reduce ventricular volume overload in tachycardiac patients, achieving spontaneous (it temporary) return to normal sinus rhythm. Since the intervention also works in heart transplant recipients, ${ }^{12}$ the most probable explanation is that sustained stretch is pro-arrhythmogenic.

The demonstration of tachycardia termination by temporary reduction in ventricular load highlights that chronic mechanical effects on heart electrophysiology are a clinically relevant target for further research. A perhaps particularly important aspect is the border zone of local (post-)ischaemic foci ${ }^{244}$, where mechanically-promoted arrhythmogenesis ${ }^{245}$ has been prevented in whole animal studies by application of a mechanical constraint that curtails ischaemic segment lengthening during contraction of the surrounding healthy myocardium. ${ }^{246}$ The same intervention delayed extracellular potassium accumulation, suggesting mechanical modulation of trans-membrane ion fluxes, perhaps involving sarcolemmal $\mathrm{K}_{\mathrm{ATP}}$ channels.

\section{Mechanical Termination of Arrhythmias}

Beyond removal of sustained overload, acute mechanical interventions, such as by precordial thump ('fist-aid'), have been known for at least a century to be of therapeutic potential. ${ }^{247}$ It is assumed that the short sharp impact to the chest is transmitted to the heart, where - presumably via activation of $\mathrm{SAC}_{\mathrm{NS}}$ - it triggers ectopic activation in excitable tissue. ${ }^{248}$ Such activation can be used to pace the quiescent heart, or to obliterate excitable gaps in hearts containing re-entrant activation waves. 
The latter scenario is less straightforward, given that excitable gaps, in particular in the presence of multiple re-entry pathways, are unlikely to be accessible from the limited extent of precordial impact locations. In addition, in conditions of severe pre-existing ischaemia, the depolarizing effect of $\mathrm{SAC}_{\mathrm{NS}}$ activation may be off-set, in part, by ischaemic and mechanical co-activation of $\mathrm{K}_{\mathrm{ATP}}$ channels, ${ }^{58}$ potentially rendering mechanically-induced depolarization less effective. ${ }^{229}$ Accordingly, early hopes, based predominantly on (publication-bias prone) case reports ${ }^{249}$ for thump-version of tachyarrhythmias, have not been sustained in more recent prospective human study designs. ${ }^{250-253}$ Accordingly, precordial thump application has been discouraged in recent ILCOR statements. ${ }^{254}$

Precordical thump-pacing in bradycardia or primary asystole, however, remains a potentially productive intervention, ${ }^{255,256}$ for example to bridge between witnessed asystolic arrest and application of electrical device-based rhythm management. ${ }^{257}$ As evident form the 2010 ILCOR statement, precordial thump in asystole warrants further investigation, taking us full circle to the original 1920 paper by Eduard Schott, who kept Stokes-Adams Syndrome patients during episodes of intermittent atrio-ventricular conduction block conscious for extended periods of time by mechanical fist-pacing only. ${ }^{247}$

\section{Outlook}

By and large, acute electrophysiological responses of the heart to mechanical stimulation can be explained, qualitatively and quantitatively, through activation of SAC. This in itself does not prove that they are sole or main drivers of responses. But, given the ability of increasingly selective pharmacological tools to probe responses in model systems from patch to patient, it seems reasonable to consider these ion channels as clinically relevant targets for management or correction of cardiac electrical activity.

So - what are the main challenges?

At the basic science end, the perhaps most important question relates to the mechanism(s) of activation of MGC. Mechanical stimuli span all scales form nano to macro (an overview of the sizes of main mechano-sensitive structures and proteins can be found in Figure 4). Their quantification in living systems is particularly challenging at cellular and sub-cellular levels.

It is known from in vitro experiments that sarcolemmal in-plane tension, curvature and thickness, lipid composition affect MGC activity. In addition, the cytoskeleton can gate MGC. Non-sarcolemmal responses, such as the stretch-induced increase in calcium spark rate for example, require the integrity, here of microtubules. ${ }^{21}$ Sarcolemmal TREK channels are inhibited by actin, ${ }^{143}$ while Piezo1 channels need the actin cytoskeleton to fully activate. ${ }^{258}$ In addition Piezo1 can be inhibited by the cyctoskeleton-protein cross-linker filamin A in smooth muscle. ${ }^{259}$ Thus, the cytoskeleton may, both, cause MGC activation or protect them from opening. An additional layer of complexity arises from the fact that cytoskeletal integrity affects membrane tension and shape of the cell and its organelles. ${ }^{260}$ This may provide a further, potentially indirect, path to affecting MGC gating. Thus, even though MGC were discovered more than 30 years ago, the actual biophysics of channel activation in vivo has remained elusive. ${ }^{261}$ 
That said, membrane 'stretch' is usually taken to be the obvious driver of MGC activation, but what are the relevant properties and descriptors of such stretch? Existence and extent of in-plan tension in membranes of cardiac cells is not known. What is known is that lipid bilayers are not distensible (strain exceeding $2-3 \%$ of 'slack area' causes membrane failure), ${ }^{262-264}$ so reservoirs (membrane invaginations, vesicles, caveolae) $)^{172,173,}, 65$ are known to buffer membrane tension variations via quick $(<100 \mathrm{~ms})^{266}$ membrane surface adaptation. ${ }^{267}$ Thus, in-plan membrane tension may not increase linearly with stretch, rising more prominently when some of the membrane reserves have been extinguished. ${ }^{268}$ This condition may be present in vitro more frequently than in vivo, as cells swell upon isolation, 'losing' structurally identifiable caveolae, and hence potentially biasing experimental observations. This could include either heighted mechano-responsiveness, or reduce differential stretch effects, as a result of pre-activation of certain mechano-sensitive pathways.

Related to tension (via the law of Laplace), but presumed to be an independent activator of MGC, membrane curvature is present both in the plasma- and in endo-membranes. Effective strains are related to size and shape of mechano-sensitive structures, and it is thought that curvatures only with radii in the range of ion channel dimensions (i.e. few nanometers) ${ }^{269}$ will act as directly relevant signals. While optical monitoring of membrane curvature in live samples (membrane patches, cells) is possible, this tracks larger radii only. A real understanding, therefore, of the biophysics involved in translating a macroscopic mechanical stimulus into a microscopic event, capable of increasing the open probability of an ion channel, is one of the key missing ingredients in developing a mechanistic understanding of mechano-electric coupling.

Thankfully, techniques are emerging that will allow quantification of mechanical properties experienced by individual cells in the tissue.

FRET (Förster Resonance Energy Transfer)-based tension probes have started to be used to assess dynamic changes in cytoskeletal tension, thus far in non-cardiac cells. This measuring approach is based on the energy transfer between two chromophores whose distance changes as a function of the mechanical environment. As the efficacy of energy transfer (which is measured as a shift in emitted fluorescence) is inversely proportional to this distance with a power of $10^{6}$, FRET probes are highly sensitive to minute changes in strain, and they can be used in vivo to characterise cytoskeletal tension in real time. ${ }^{221,277,278} \mathrm{~A}$ conceptually similar approach is being taken towards assessment membrane mechanical properties in native cells. Using a FRET tension probe, inserted into a mechano-sensitive protein, is has been possible to track conformational changes at the ion channel level in living cells. ${ }^{279}$ Constructs like this could be used as tension reporters for various lipid bilayers, including non-sarcolemmal membranes.

At the applied end, one of the key challenges is to identify the molecular nature of individual ion channels involved in electrophysiological responses of the human heart to changes in the mechanical environment. Building on that, intervention tools that are organ-, or better cell- and/or disease-state specific, may hold a key to novel therapeutic opportunities. 
A more long-term aim will be to decipher the complex pathways of mechanically induced changes in cell and tissue structure and function, which contribute to chronic responses to mechanical overload. Given that we are still unsure whether stress or strain are 'the' key activators of MGC, it is difficult to decipher response patterns driven by volume- and pressure-challenges (or by pre- and afterload) in the whole organ.

The most complex setting - chronic overload combined with acute stretch (such as may occur in ischaemic border zone tissue, for example) - is perhaps the clinically most relevant immediate target, as focal excitation occurs acutely, and in relation to local stretch maxima. An MGC modulator that would be metabolic state-specific (e.g. perhaps $\mathrm{pH}$-dependent) could potentially be applied systemically, yet act where needed. This is an area deserving targeted study.

Another challenge lies in the multiplicity of non-channel structures that are mechanosensitive, ${ }^{280}$ making an understanding of the roles of mechanical forces more complex.

Caveolae are known to act as membrane reserves that can buffer variation of membrane tension. They were shown to limit $\mathrm{VAC}\left(\mathrm{I}_{\mathrm{Cl} \text {,swell }}\right)$ activation in rat ventricular myocytes, ${ }^{267}$ and are implied as the substrate for stretch-induced conduction slowing (acting via mechanical unfolding, increasing effective surface membrane area). ${ }^{173}$

Also, Caveolin3 (Cav3) can modify integrin function and mechano-transduction in cardiomyocytes and intact heart, ${ }^{281}$ while Cav1 in endothelial cells of murine coronary arteries is a critical requirement for shear stress-mediated vasodilatation. ${ }^{282}$ Caveolins are also tightly linked to some TRP-channels, making caveolae another most interesting component of mechanical transduction pathways, including those relevant for MEF.

Last, but not least, T-tub - sarcolemmal membrane invaginations that dive deep into the centre of cardiac myocytes - contain MGC (TRPC6) and MMC (Kir2.3). ${ }^{49}$ They deform rhythmically on a beat-by-beat basis ${ }^{172,283}$ and may be one of the more under-estimated physiologically-relevant mechano-transducers in the heart. For a more extensive overview of non-channel structures involved in mechano-transduction processes we refer to Hirata et al. ${ }^{280}$

\section{Conclusion}

MGC in the heart affect cardiac electrophysiology. While mechanical activation of ion transport pathways may be an evolutionary inheritance of the need, even for the earliest cells, to respond to osmotic challenges, SAC in (osmotically more stable) multicellular systems may have conferred other advantages. For muscle cells, this may include the adjustment of contractility to local mechanical demand. The fact that MGC carry ion currents that can affect heart rate and rhythm may, thus, be a 'side effect'. But, even if so, it is one that matters for maintenance of normal heart rate and for the induction or termination of heart rhythm disturbances. Any therapeutic targeting will need to involve a three-pronged approach, that considers potential electrophysiological benefits in the context of the need to maintain volume regulatory capacity (say in ischaemia, and even more so, reperfusion) and the ability to tune cell contractility to the mechanical environment. In fact, the latter is 
particularly important for the heart as, in contrast to skeletal muscle, individual myocytes must 'match' their mechanical performance to that of their neighbours in the absence of neuro-muscular junctions or other cell-external mechanisms to grade contractile activity. What is clear, though, is that any concept of cardiac electro-mechanical activity that ignores the information flow from mechanics to electrics is unnecessarily limited - and outdated.

\section{Supplementary Material}

Refer to Web version on PubMed Central for supplementary material.

\section{Acknowledgments}

Sources of funding:

British Heart Foundation (PK), European Research Council (PK), Magdi Yacoub Institute (PK, RP); National Heart Lung and Blood Institute of the National Institutes of Health, R01-HL03461 (JMN); RP is an Imperial College Research Fellow, PK is a Senior Fellow of the British Heart Foundation.

\section{Nonstandard Abbreviations and Acronyms}

$\operatorname{AChR}$

AP

APD

ASIC

BK

CaT

$\mathrm{Ca}_{\mathbf{v}}$

$\left[\mathrm{Ca}^{2+}\right]_{\mathbf{i}}$

$\mathrm{CC}$

CFTR

CLC

GluN2B

$\mathbf{K}_{\mathrm{ATP}}$

$\mathbf{K}_{2 P}$

KCNQ

Kir

Kv

KvAP

MCA

MEC
AcetylCholine Receptor

Action Potential

Action Potential Duration

Acid-Sensing Ion Channel

Big $\mathbf{K}^{+}$channels

Calcium Transient

Calcium channels Voltage-gated

Calcium concentration, intracellular

Commotio cordis

Cystic Fibrosis Transmembrane Conductance Regulator

Cholride Channels

GluRepsilon2/NR2B

$\mathbf{K}^{+}$channel, ATP-inactivated

$\mathbf{K}^{+}$channels with $\mathbf{2} \mathbf{P}$ domains

$\mathbf{K}^{+}$Channel, voltage gated, KQT-like

$\mathbf{K}^{+}$inwardly-rectifying channel

$\mathbf{K}^{+}$channel Voltage-gated

$\mathbf{K}^{+}$channel Voltage-gated from Aeropyrum pernix

Mechano-sensitive $\mathbf{C a}^{2+}$ channel

Mechanosensory abnormal 
MGC

Mid1

MscA

MscK, L, M, S

MscMJ

MSC1

MSL

$\mathrm{Na}_{\mathbf{v}}$

NMDA

NOMPC

OSM

ROS

RyR

SAC

$\mathrm{SAC}_{\mathrm{K}}$

SAC $_{\text {NS }}$

SL

SAN

TASK-1

TPK

TRAAK

TREK

TRP

TRPA, C, M, N, P, V, $\mathbf{Y}$

T-tub

TWIK

VAC

VF
Mechano-Gated Channels

Mating Induced Death

Mechanso-sensitive channel Archaeon

Mechanso-sensitive channel of $\mathbf{K}^{+}$, Large, Medium, Small conductance

Mechanso-sensitive channel of Methanococcus jannashii

$\mathbf{M s c S}$ homolog in Chlamydomonas reinhardtii

Mechanso-sensitive channel of Small conductance like

Sodium selective channel Voltage-gated

$N$-methyl-D-aspartate

No mechanoreceptor potential C

OSMotic avoidance abnormal family

Reactive Oxygen Species

Ryanodine Receptor

Stretch-Activated Channels

SAC, $\mathbf{K}^{+}$-selective

SAC, cation non-selective

Sarcomere length

Sino-Atrial Node

TWIK-related acid-sensitive $\mathbf{K}^{+}$channel

Two-pore $\mathbf{K}^{+}$channels

TWIK-related arachidonic acid-activated $\mathbf{K}^{+}$channel

TWIK-related $\mathbf{K}^{+}$channel

Transient Receptor Potential

Transient Receptor Potential Ankyrin, Canonical, Melastatin, NOMP, Polycystin, Vanilloid, Yeast

Transverse tubule

Tandem of two-pore $\mathrm{K}^{+}$domains in a weak inwardly rectifying $\mathbf{K}^{+}$channel

Cell Volume-Activated Channels

Ventricular Fibrillation 


\section{References}

1. Nélaton, A. Elements de pathologie chirurgicale. Librairie Germer Bateliere et Co; 1876.

2. Meola F. La commozione toracica. Gior Internaz Sci Med. 1879; 1:923-37.

3. Kohl P, Nesbitt AD, Cooper PJ, Lei M. Sudden cardiac death by Commotio cordis: role of mechano-electric feedback. Cardiovasc Res. 2001; 50:280-9. [PubMed: 11334832]

4. Nesbitt AD, Cooper PJ, Kohl P. Rediscovering commotio cordis. Lancet. 2001; 357:1195-7. [PubMed: 11323067]

5. Langendorff O. Untersuchungen am überlebenden Säugethierherzen. Pflügers Archiv Eur J Phy. $1895 ; 61: 291-332$.

6. Zimmer HG. Who discovered the Frank-Starling mechanism? News in Physiol Sci. 2002; 17:181184. [PubMed: 12270953]

7. Frank O. Die Grundform des arteriellen Pulses. Zeitschrift für Biologie. 1899; 37:483-526.

8. Starling, E. The law of the heart. Linacre Lecture; Cambridge: 1918.

9. Campbell KS. Impact of myocyte strain on cardiac myofilament activation. Pflugers Archiv-Eur J Physiol. 2011; 462:3-14. [PubMed: 21409385]

10. Kaufmann R, Theophile U. Autonomously promoted extension effect in Purkinje fibers, papillary muscles and trabeculae carneae of rhesus monkeys. Pflügers Archiv für die gesamte Physiologie des Menschen und der Tiere. 1967; 297:174.

11. Bainbridge FA. The influence of venous filling upon the rate of the heart. J Physiol. 1915; 50:6584. [PubMed: 16993330]

12. Ambrosi P, Habib G, Kreitmann B, Faugere G, Metras D. Valsalva manoeuvre for supraventricular tachycardia in transplanted heart recipient. Lancet. 1995; 346:713. [PubMed: 7658862]

13. Bernardi L, Salvucci F, Suardi R, Solda PL, Calciati A, Perlini S, Falcone C, Ricciardi L. Evidence for an intrinsic mechanism regulating heart rate variability in the transplanted and the intact heart during submaximal dynamic exercise? Cardiovasc Res. 1990; 24:969-81. [PubMed: 2097063]

14. Bernardi L, Keller F, Sanders M, Reddy PS, Griffith B, Meno F, Pinsky MR. Respiratory sinus arrhythmia in the denervated human heart. J Appl Physiol. 1989; 67:1447-55. [PubMed: 2793748]

15. Franz MR, Cima R, Wang D, Profitt D, Kurz R. Electrophysiological effects of myocardial stretch and mechanical determinants of stretch-activated arrhythmias. Circulation. 1992; 86:968-78. [PubMed: 1381296]

16. Blinks JR. Positive chronotropic effect of increasing right atrial pressure in the isolated mammalian heart. Am J Physiol. 1956; 186:299-303. [PubMed: 13362527]

17. Keatinge WR. The effect of increased filling pressure on rhythmicity and atrioventricular conduction in isolated hearts. J Physiol. 1959; 149:193-208. [PubMed: 14405070]

18. Markhasin VS, Solovyova O, Katsnelson LB, Protsenko Y, Kohl P, Noble D. Mechano-electric interactions in heterogeneous myocardium: development of fundamental experimental and theoretical models. Prog Biophys Mol Biol. 2003; 82:207-20. [PubMed: 12732280]

19. ter Keurs HE, Shinozaki T, Zhang YM, Zhang ML, Wakayama Y, Sugai Y, Kagaya Y, Miura M, Boyden PA, Stuyvers BD, Landesberg A. Sarcomere mechanics in uniform and non-uniform cardiac muscle: a link between pump function and arrhythmias. Prog Biophys Mol Biol. 2008; 97:312-31. [PubMed: 18394686]

20. Cooper PJ, Lei M, Cheng LX, Kohl P. Selected contribution: axial stretch increases spontaneous pacemaker activity in rabbit isolated sinoatrial node cells. J App Physiol. 2000; 89:2099-104.

21. Iribe G, Ward CW, Camelliti P, Bollensdorff C, Mason F, Burton RA, Garny A, Morphew MK, Hoenger A, Lederer WJ, Kohl P. Axial stretch of rat single ventricular cardiomyocytes causes an acute and transient increase in $\mathrm{Ca}^{2+}$ spark rate. Circ Res. 2009; 104:787-95. [PubMed: 19197074]

22. Gannier F, White E, Lacampagne A, Garnier D, Le Guennec JY. Streptomycin reverses a large stretch induced increases in $\left[\mathrm{Ca}^{2+}\right]_{\mathrm{i}}$ in isolated guinea pig ventricular myocytes. Cardiovasc Res. 1994; 28:1193-8. [PubMed: 7954622]

23. Craelius W. Stretch-activation of rat cardiac myocytes. Experimental Physiology. 1993; 78:41123. [PubMed: 7687136] 
24. Iribe G, Helmes M, Kohl P. Force-length relations in isolated intact cardiomyocytes subjected to dynamic changes in mechanical load. Am J Physiol Heart Circ Physiol. 2007; 292:H1487-97. [PubMed: 17098830]

25. Kohl P, Kamkin AG, Kiseleva IS, Streubel T. Mechanosensitive cells in the atrium of frog heart. Exp Physiol. 1992; 77:213-6. [PubMed: 1543586]

26. Kiseleva I, Kamkin A, Kohl P, Lab MJ. Calcium and Mechanically induced potentials in fibroblasts of rat atrium. Cardiovasc Res. 1996; 32:98-111. [PubMed: 8776407]

27. Kamkin A, Kirischuk S, Kiseleva I. Single mechano-gated channels activated by mechanical deformation of acutely isolated cardiac fibroblasts from rats. Acta Physiol (Oxf). 2010; 199:27792. [PubMed: 20102342]

28. Kohl, P.; Sachs, F.; Franz, MR. Cardiac Mechano-Electric Coupling and Arrhythmias. 2. Oxford: Oxford University Press; 2011.

29. Guharay F, Sachs F. Stretch-activated single ion channel currents in tissue-cultured embryonic chick skeletal muscle. J Physiol. 1984; 352:685-701. [PubMed: 6086918]

30. Craelius W, Chen V, el-Sherif N. Stretch activated ion channels in ventricular myocytes. Biosci Rep. 1988; 8:407-14. [PubMed: 2852974]

31. Reed A, Kohl P, Peyronnet R. Molecular candidates for cardiac stretch-activated ion channels. Global cardiology science \& practice. 2014; 2014:9. [PubMed: 25405172]

32. Kim D. A mechanosensitive $\mathrm{K}^{+}$channel in heart cells. Activation by arachidonic acid. J Gen Physiol. 1992; 100:1021-40. [PubMed: 1484283]

33. Wang W, Zhang M, Li P, Yuan H, Feng N, Peng Y, Wang L, Wang X. An increased TREK-1-like potassium current in ventricular myocytes during rat cardiac hypertrophy. J Cardiovasc Pharm. 2013; 61:302-10.

34. Sukharev SI, Martinac B, Blount P, Kung C. Functional reconstitution as an assay for biochemical isolation of channel proteins: application to the molecular identification of a bacterial mechanosensitive channel. Methods. 1994; 6:51-59.

35. Patel AJ, Honore E, Maingret F, Lesage F, Fink M, Duprat F, Lazdunski M. A mammalian two pore domain mechano-gated S-like $\mathrm{K}^{+}$channel. The EMBO Journal. 1998; 17:4283-90. [PubMed: 9687497]

36. Bode F, Sachs F, Franz MR. Tarantula peptide inhibits atrial fibrillation. Nature. 2001; 409:35-6. [PubMed: 11343101]

37. Hansen DE, Borganelli M, Stacy GP Jr, Taylor LK. Dose-dependent inhibition of stretch-induced arrhythmias by gadolinium in isolated canine ventricles. Evidence for a unique mode of antiarrhythmic action. Circ Res. 1991; 69:820-31. [PubMed: 1873875]

38. McBride DW Jr, Hamill OP. Pressure-clamp: a method for rapid step perturbation of mechanosensitive channels. Pflugers Arch. 1992; 421:606-12. [PubMed: 1279516]

39. Hurwitz CG, Segal AS. Application of pressure steps to mechanosensitive channels in membrane patches: a simple, economical, and fast system. Pflugers Arch. 2001; 442:150-6. [PubMed: 11374063]

40. Coste B, Mathur J, Schmidt M, Earley TJ, Ranade S, Petrus MJ, Dubin AE, Patapoutian A. Piezo1 and Piezo2 are essential components of distinct mechanically activated cation channels. Science. 2010; 330:55-60. [PubMed: 20813920]

41. Laitko U, Morris CE. Membrane tension accelerates rate-limiting voltage-dependent activation and slow inactivation steps in a Shaker channel. J Gen Physiol. 2004; 123:135-54. [PubMed: 14744987]

42. Farrugia G, Holm AN, Rich A, Sarr MG, Szurszewski JH, Rae JL. A mechanosensitive calcium channel in human intestinal smooth muscle cells. Gastroenterology. 1999; 117:900-5. [PubMed: 10500073]

43. Calabrese B, Tabarean IV, Juranka P, Morris CE. Mechanosensitivity of N-type calcium channel currents. Biophys J. 2002; 83:2560-74. [PubMed: 12414690]

44. Kraichely RE, Strege PR, Sarr MG, Kendrick ML, Farrugia G. Lysophosphatidyl choline modulates mechanosensitive L-type $\mathrm{Ca}^{2+}$ current in circular smooth muscle cells from human jejunum. Am J Physiol Gastrointest Liver Physiol. 2009; 296:G833-9. [PubMed: 19179622] 
45. Tabarean IV, Juranka P, Morris CE. Membrane stretch affects gating modes of a skeletal muscle sodium channel. Biophys J. 1999; 77:758-74. [PubMed: 10423424]

46. Morris CE, Juranka PF. Nav channel mechanosensitivity: activation and inactivation accelerate reversibly with stretch. Biophys J. 2007; 93:822-33. [PubMed: 17496023]

47. Wang JA, Lin W, Morris T, Banderali U, Juranka PF, Morris CE. Membrane trauma and $\mathrm{Na}^{+}$leak from Nav1.6 channels. Am J Physiol Cell Physiol. 2009; 297:C823-34. [PubMed: 19657055]

48. Boycott HE, Barbier CS, Eichel CA, Costa KD, Martins RP, Louault F, Dilanian G, Coulombe A, Hatem SN, Balse E. Shear stress triggers insertion of voltage-gated potassium channels from intracellular compartments in atrial myocytes. Proc Natl Acad Sci U S A. 2013; 110:E3955-64. [PubMed: 24065831]

49. Dyachenko V, Husse B, Rueckschloss U, Isenberg G. Mechanical deformation of ventricular myocytes modulates both TRPC6 and Kir2.3 channels. Cell Calcium. 2009; 45:38-54. [PubMed: 18635261]

50. Beyder A, Rae JL, Bernard C, Strege PR, Sachs F, Farrugia G. Mechanosensitivity of Nav1.5, a voltage-sensitive sodium channel. J Physiol. 2010; 588:4969-85. [PubMed: 21041530]

51. Pedrozo Z, Criollo A, Battiprolu PK, Morales CR, Contreras-Ferrat A, Fernandez C, Jiang N, Luo X, Caplan MJ, Somlo S, Rothermel BA, Gillette TG, Lavandero S, Hill JA. Polycystin-1 Is a Cardiomyocyte Mechanosensor That Governs L-Type $\mathrm{Ca}^{2+}$ Channel Protein Stability. Circulation. 2015; 131:2131-42. [PubMed: 25888683]

52. Schmidt D, MacKinnon R. Voltage-dependent $\mathrm{K}^{+}$channel gating and voltage sensor toxin sensitivity depend on the mechanical state of the lipid membrane. Proc Natl Acad Sci U S A. 2008; 105:19276-81. [PubMed: 19050073]

53. Peyronnet R, Sharif-Naeini R, Folgering JH, Arhatte M, Jodar M, El Boustany C, Gallian C, Tauc M, Duranton C, Rubera I, Lesage F, Pei Y, Peters DJ, Somlo S, Sachs F, Patel A, Honore E, Duprat F. Mechanoprotection by polycystins against apoptosis is mediated through the opening of stretch-activated $\mathrm{K}_{2 \mathrm{P}}$ channels. Cell Rep. 2012; 1:241-50. [PubMed: 22832196]

54. Bentzen BH, Grunnet M. Central and Peripheral GABA(A) Receptor Regulation of the Heart Rate Depends on the Conscious State of the Animal. Adv Pharmacol Sci. 2011; 2011:578273. [PubMed: 22162673]

55. Ralevic V. P2X receptors in the cardiovascular system. Wiley Interdisciplinary Reviews: Membrane Transport and Signaling. 2012; 1:663-674.

56. Kessler S, Clauss WG, Fronius M. Laminar shear stress modulates the activity of heterologously expressed P2X 4 receptors. Biochim Biophys Acta. 2011; 1808:2488-95. [PubMed: 21798232]

57. Noma A. ATP-regulated $\mathrm{K}^{+}$channels in cardiac muscle. Nature. 1983; 305:147-8. [PubMed: 6310409]

58. Van Wagoner DR. Mechanosensitive gating of atrial ATP-sensitive potassium channels. Circ Res. 1993; 72:973-83. [PubMed: 8477531]

59. Inagaki N, Gonoi T, Clement JPt, Namba N, Inazawa J, Gonzalez G, Aguilar-Bryan L, Seino S, Bryan J. Reconstitution of $\mathrm{IK}_{\mathrm{ATP}}$ : an inward rectifier subunit plus the sulfonylurea receptor. Science. 1995; 270:1166-70. [PubMed: 7502040]

60. Aguilar-Bryan L, Nichols CG, Wechsler SW, Clement JPt, Boyd AE 3rd, Gonzalez G, HerreraSosa H, Nguy K, Bryan J, Nelson DA. Cloning of the beta cell high-affinity sulfonylurea receptor: a regulator of insulin secretion. Science. 1995; 268:423-6. [PubMed: 7716547]

61. Morrissey A, Rosner E, Lanning J, Parachuru L, Dhar Chowdhury P, Han S, Lopez G, Tong X, Yoshida H, Nakamura TY, Artman M, Giblin JP, Tinker A, Coetzee WA. Immunolocalization of $\mathrm{K}_{\mathrm{ATP}}$ channel subunits in mouse and rat cardiac myocytes and the coronary vasculature. BMC Physiol. 2005; 5:1. [PubMed: 15647111]

62. Miki T, Suzuki M, Shibasaki T, Uemura H, Sato T, Yamaguchi K, Koseki H, Iwanaga T, Nakaya $\mathrm{H}$, Seino S. Mouse model of Prinzmetal angina by disruption of the inward rectifier Kir6.1. Nat Med. 2002; 8:466-72. [PubMed: 11984590]

63. Fedorov VV, Glukhov AV, Ambrosi CM, Kostecki G, Chang R, Janks D, Schuessler RB, Moazami N, Nichols CG, Efimov IR. Effects of $\mathrm{K}_{\mathrm{ATP}}$ channel openers diazoxide and pinacidil in coronary-perfused atria and ventricles from failing and non-failing human hearts. J Mol Cell Cardiol. 2011; 51:215-25. [PubMed: 21586291] 
64. Kohl P, Bollensdorff C, Garny A. Effects of mechanosensitive ion channels on ventricular electrophysiology: experimental and theoretical models. Exp Physiol. 2006; 91:307-21. [PubMed: 16407474]

65. Huang H, Liang L, Liu P, Wei H, Sachs F, Niu W, Wang W. Mechanical Effects on $\mathrm{K}_{\text {ATP }}$ Channel Gating in Rat Ventricular Myocytes. PloS One. 2013; 8:e63337. [PubMed: 23691027]

66. Cole WC, McPherson CD, Sontag D. ATP-regulated $\mathrm{K}^{+}$channels protect the myocardium against ischemia/reperfusion damage. Circ Res. 1991; 69:571-81. [PubMed: 1908354]

67. Takahashi K, Kakimoto Y, Toda K, Naruse K. Mechanobiology in cardiac physiology and diseases. J Cell Mol Med. 2013; 17:225-232. [PubMed: 23441631]

68. Benamer N, Vasquez C, Mahoney VM, Steinhardt MJ, Coetzee WA, Morley GE. Fibroblast KATP currents modulate myocyte electrophysiology in infarcted hearts. Am J Physiol Heart and Circ Physiol. 2013; 304:H1231-9. [PubMed: 23436329]

69. Bell RM, Yellon DM. Conditioning the whole heart--not just the cardiomyocyte. J Mol Cell Cardiol. 2012; 53:24-32. [PubMed: 22521304]

70. Abrial M, Da Silva CC, Pillot B, Augeul L, Ivanes F, Teixeira G, Cartier R, Angoulvant D, Ovize M, Ferrera R. Cardiac fibroblasts protect cardiomyocytes against lethal ischemia-reperfusion injury. J Mol Cell Cardiol. 2014

71. Baumgarten CM, Clemo HF. Swelling-activated chloride channels in cardiac physiology and pathophysiology. Prog Biophys Mol Biol. 2003; 82:25-42. [PubMed: 12732266]

72. Matsuda N, Hagiwara N, Shoda M, Kasanuki H, Hosoda S. Enhancement of the L-type $\mathrm{Ca}^{2+}$ current by mechanical stimulation in single rabbit cardiac myocytes. Circ Res. 1996; 78:650-9. [PubMed: 8635223]

73. Gomis A, Soriano S, Belmonte C, Viana F. Hypoosmotic- and pressure-induced membrane stretch activate TRPC5 channels. J Physiol. 2008; 586:5633-49. [PubMed: 18832422]

74. Bett GCL, Sachs F. Whole-cell mechanosensitive currents in rat ventricular myocytes activated by direct stimulation. J Memb Biol. 2000; 173:255-263.

75. Vandenberg JI, Rees SA, Wright AR, Powell T. Cell swelling and ion transport pathways in cardiac myocytes. Cardiovasc Res. 1996; 32:85-97. [PubMed: 8776406]

76. Qiu Z, Dubin AE, Mathur J, Tu B, Reddy K, Miraglia LJ, Reinhardt J, Orth AP, Patapoutian A. SWELL1, a plasma membrane protein, is an essential component of volume-regulated anion channel. Cell. 2014; 157:447-58. [PubMed: 24725410]

77. Voss FK, Ullrich F, Munch J, Lazarow K, Lutter D, Mah N, Andrade-Navarro MA, von Kries JP, Stauber T, Jentsch TJ. Identification of LRRC8 heteromers as an essential component of the volume-regulated anion channel VRAC. Science. 2014; 344:634-8. [PubMed: 24790029]

78. Opsahl LR, Webb WW. Transduction of membrane tension by the ion channel alamethicin. Biophys J. 1994; 66:71-4. [PubMed: 7510531]

79. Brohawn SG, Su Z, MacKinnon R. Mechanosensitivity is mediated directly by the lipid membrane in TRAAK and TREK1 K ${ }^{+}$channels. Proc Natl Acad Sci U S A. 2014; 111:3614-9. [PubMed: 24550493]

80. Berrier C, Pozza A, de Lavalette AD, Chardonnet S, Mesneau A, Jaxel C, le Maire M, Ghazi A. The Purified Mechanosensitive Channel TREK-1 Is Directly Sensitive to Membrane Tension. J Biol Chem. 2013; 288:27307-27314. [PubMed: 23897808]

81. Bett GCL, Sachs F. Activation and inactivation of mechanosensitive currents in the chick heart. J Memb Biol. 2000; 173:237-254.

82. Gottlieb P, Folgering J, Maroto R, Raso A, Wood TG, Kurosky A, Bowman C, Bichet D, Patel A, Sachs F, Martinac B, Hamill OP, Honore E. Revisiting TRPC1 and TRPC6 mechanosensitivity. Pflugers Archiv: Eur J Physiol. 2008; 455:1097-103. [PubMed: 17957383]

83. Moulik M, Vatta M, Witt SH, Arola AM, Murphy RT, McKenna WJ, Boriek AM, Oka K, Labeit S, Bowles NE, Arimura T, Kimura A, Towbin JA. ANKRD1, the gene encoding cardiac ankyrin repeat protein, is a novel dilated cardiomyopathy gene. J Am Coll Cardiol. 2009; 54:325-33. [PubMed: 19608030]

84. Lammerding J, Schulze PC, Takahashi T, Kozlov S, Sullivan T, Kamm RD, Stewart CL, Lee RT. Lamin A/C deficiency causes defective nuclear mechanics and mechanotransduction. J Clin Invest. 2004; 113:370-8. [PubMed: 14755334] 
85. van Tintelen JP, Entius MM, Bhuiyan ZA, Jongbloed R, Wiesfeld AC, Wilde AA, van der Smagt J, Boven LG, Mannens MM, van Langen IM, Hofstra RM, Otterspoor LC, Doevendans PA, Rodriguez LM, van Gelder IC, Hauer RN. Plakophilin-2 mutations are the major determinant of familial arrhythmogenic right ventricular dysplasia/cardiomyopathy. Circulation. 2006; 113:16508. [PubMed: 16567567]

86. Stroud MJ, Banerjee I, Veevers J, Chen J. Linker of nucleoskeleton and cytoskeleton complex proteins in cardiac structure, function, and disease. Circ Res. 2014; 114:538-48. [PubMed: 24481844]

87. Ackerman MJ, Mohler PJ. Defining a new paradigm for human arrhythmia syndromes: phenotypic manifestations of gene mutations in ion channel- and transporter-associated proteins. Circ Res. 2010; 107:457-65. [PubMed: 20724725]

88. Smith SA, Sturm AC, Curran J, Kline CF, Little SC, Bonilla IM, Long VP, Makara M, Polina I, Hughes LD, Webb TR, Wei Z, Wright P, Voigt N, Bhakta D, Spoonamore KG, Zhang C, Weiss R, Binkley PF, Janssen PM, Kilic A, Higgins RS, Sun M, Ma J, Dobrev D, Zhang M, Carnes CA, Vatta M, Rasband MN, Hund TJ, Mohler PJ. Dysfunction in the betaII spectrin-dependent cytoskeleton underlies human arrhythmia. Circulation. 2015; 131:695-708. [PubMed: 25632041]

89. Steinbacher S, Bass R, Strop P, Rees DC. Structures of the prokaryotic mechanosensitive channels MscL and MscS. Mechanosensitive Ion Channels, Part A. 2007; 58:1-24.

90. Haswell ES, Phillips R, Rees DC. Mechanosensitive Channels: What Can They Do and How Do They Do It? Structure. 2011; 19:1356-1369. [PubMed: 22000509]

91. Hamilton ES, Schlegel AM, Haswell ES. United in Diversity: Mechanosensitive Ion Channels in Plants. Annu Rev Plant Biol. 2014

92. Anishkin A, Loukin SH, Teng J, Kung C. Feeling the hidden mechanical forces in lipid bilayer is an original sense. Proc Natl Acad Sci U S A. 2014; 111:7898-905. [PubMed: 24850861]

93. Sachs F, Morris CE. Mechanosensitive ion channels in nonspecialized cells. Revi Physiol, Biochem Pharmacol. 1998; 132:1-77.

94. Peyronnet R, Tran D, Girault T, Frachisse JM. Mechanosensitive channels: feeling tension in a world under pressure. Front Plant Sci. 2014; 5:558. [PubMed: 25374575]

95. Sukharev SI, Blount P, Martinac B, Blattner FR, Kung C. A large-conductance mechanosensitive channel in E. coli encoded by mscL alone. Nature. 1994; 368:265-8. [PubMed: 7511799]

96. Chang G, Spencer RH, Lee AT, Barclay MT, Rees DC. Structure of the MscL homolog from Mycobacterium tuberculosis: a gated mechanosensitive ion channel. Science. 1998; 282:2220-6. [PubMed: 9856938]

97. Bass RB, Strop P, Barclay M, Rees DC. Crystal structure of Escherichia coli MscS, a voltagemodulated and mechanosensitive channel. Science. 2002; 298:1582-7. [PubMed: 12446901]

98. Brohawn SG, del Marmol J, MacKinnon R. Crystal structure of the human $\mathrm{K}_{2 \mathrm{P}}$ TRAAK, a lipidand mechano-sensitive $\mathrm{K}^{+}$ion channel. Science. 2012; 335:436-41. [PubMed: 22282805]

99. Ge J, Li W, Zhao Q, Li N, Chen M, Zhi P, Li R, Gao N, Xiao B, Yang M. Architecture of the mammalian mechanosensitive Piezo1 channel. Nature. 2015; 527:64-9. [PubMed: 26390154]

100. Wu YK, Yang Y, Ye S, Jiang YX. Structure of the gating ring from the human large-conductance $\mathrm{Ca}^{2+}$-gated ${ }^{+}$channel. Nature. 2010; 466:393-U148. [PubMed: 20574420]

101. Bhargava A, Lin XM, Novak P, Mehta K, Korchev Y, Delmar M, Gorelik J. Super-resolution Scanning Patch Clamp Reveals Clustering of Functional Ion Channels in Adult Ventricular Myocyte. Circulation Research. 2013; 112:1112. [PubMed: 23438901]

102. Haswell ES, Meyerowitz EM. MscS-like proteins control plastid size and shape in Arabidopsis thaliana. Curr Biol. 2006; 16:1-11. [PubMed: 16401419]

103. Nakayama Y, Yoshimura K, Iida H. Organellar mechanosensitive channels in fission yeast regulate the hypo-osmotic shock response. Nat Commun. 2012; 3:1020. [PubMed: 22910366]

104. Belmonte S, Morad M. Shear fluid-induced $\mathrm{Ca}^{2+}$ release and the role of mitochondria in rat cardiac myocytes. Annals of the New York Academy of Sciences. 2008; 1123:58-63. [PubMed: 18375577]

105. Traister A, Li M, Aafaqi S, Lu ML, Arab S, Radisic M, Gross G, Guido F, Sherret J, Verma S, Slorach C, Mertens L, Hui W, Roy A, Delgado-Olguin P, Hannigan G, Maynes JT, Coles JG. 
Integrin-linked kinase mediates force transduction in cardiomyocytes by modulating SERCA2a/PLN function. Nature Communications. 2014:5.

106. White E. Mechanosensitive channels: therapeutic targets in the myocardium? Current Pharmaceutical Design. 2006; 12:3645-63. [PubMed: 17073665]

107. O'Rourke B. Evidence for mitochondrial $\mathrm{K}^{+}$channels and their role in cardioprotection. Circ Res. 2004; 94:420-32. [PubMed: 15001541]

108. Yang XM, Proctor JB, Cui L, Krieg T, Downey JM, Cohen MV. Multiple, brief coronary occlusions during early reperfusion protect rabbit hearts by targeting cell signaling pathways. $\mathbf{J}$ Am Coll Cardiol. 2004; 44:1103-10. [PubMed: 15337225]

109. Mykytenko J, Reeves JG, Kin H, Wang NP, Zatta AJ, Jiang R, Guyton RA, Vinten-Johansen J, Zhao ZQ. Persistent beneficial effect of postconditioning against infarct size: role of mitochondrial K(ATP) channels during reperfusion. Basic Res Cardiol. 2008; 103:472-84. [PubMed: 18600365]

110. Swyers T, Redford D, Larson DF. Volatile anesthetic-induced preconditioning. Perfusion. 2014; 29:10-5. [PubMed: 24002781]

111. Guilak F. Compression-induced changes in the shape and volume of the chondrocyte nucleus. $\mathbf{J}$ Biomech. 1995; 28:1529-41. [PubMed: 8666592]

112. Versaevel M, Grevesse T, Gabriele S. Spatial coordination between cell and nuclear shape within micropatterned endothelial cells. Nat Commun. 2012; 3:671. [PubMed: 22334074]

113. Rowat AC, Lammerding J, Ipsen JH. Mechanical properties of the cell nucleus and the effect of emerin deficiency. Biophys J. 2006; 91:4649-64. [PubMed: 16997877]

114. Fedorchak GR, Kaminski A, Lammerding J. Cellular mechanosensing: getting to the nucleus of it all. Prog Biophys Mol Biol. 2014; 115:76-92. [PubMed: 25008017]

115. Zhao Y, Huang H, Jiang Y, Wei H, Liu P, Wang W, Niu W. Unusual localization and translocation of TRPV4 protein in cultured ventricular myocytes of the neonatal rat. European Journal of Histochemistry: EJH. 2012; 56:e32. [PubMed: 23027348]

116. Lansman JB, Hallam TJ, Rink TJ. Single Stretch-Activated Ion Channels in Vascular EndothelialCells as Mechanotransducers. Nature. 1987; 325:811-813. [PubMed: 2434860]

117. Popp R, Hoyer J, Meyer J, Galla HJ, Gogelein H. Stretch-Activated Nonselective Cation Channels in the Antiluminal Membrane of Porcine Cerebral Capillaries. J Physiol - London. 1992; 454:435-449. [PubMed: 1282158]

118. Naruse K, Yamada T, Sokabe M. Involvement of SA channels in orienting response of cultured endothelial cells to cyclic stretch. Am J Physiol Heart Circ Physiol. 1998; 274:H1532-H1538.

119. Yue ZC, Zhang YH, Xie J, Jiang JM, Yue LX. Transient Receptor Potential (TRP) Channels and Cardiac Fibrosis. Curr Top Med Chem. 2013; 13:270-282. [PubMed: 23432060]

120. Stockbridge LL, French AS. Stretch-Activated Cation Channels in Human-Fibroblasts. Biophys J. 1988; 54:187-190. [PubMed: 2458140]

121. Glogauer M, Ferrier J, Mcculloch CAG. Magnetic-Fields Applied to Collagen-Coated FerricOxide Beads Induce Stretch-Activated $\mathrm{Ca}^{2+}$ Flux in Fibroblasts. Am J Physiol Cell Physiol. 1995; 269:C1093-C1104.

122. Blaauw E, Lorenzen-Schmidt I, Babiker FA, Munts C, Prinzen FW, Snoeckx LH, van Bilsen M, van der Vusse GJ, van Nieuwenhoven FA. Stretch-induced upregulation of connective tissue growth factor in rabbit cardiomyocytes. J Cardiovasc Transl Res. 2013; 6:861-9. [PubMed: 23835778]

123. Camelliti P, Green CR, LeGrice I, Kohl P. Fibroblast network in rabbit sinoatrial node Structural and functional identification of homogeneous and heterogeneous cell coupling. Circ Res. 2004; 94:828-835. [PubMed: 14976125]

124. Kohl P, Camelliti P. Fibroblast-myocyte connections in the heart. Heart Rhythm. 2012; 9:461464. [PubMed: 21978963]

125. Camelliti P, Borg TK, Kohl P. Structural and functional characterisation of cardiac fibroblasts. Cardiovasc Res. 2005; 65:40-51. [PubMed: 15621032]

126. Camelliti P, Devlin GP, Matthews KG, Kohl P, Green CR. Spatially and temporally distinct expression of fibroblast connexins after sheep ventricular infarction. Cardiovasc Res. 2004; 62:415-425. [PubMed: 15094361] 
127. Kohl P, Camelliti P, Burton FL, Smith GL. Electrical coupling of fibroblasts and myocytes: relevance for cardiac propagation. J Electrocardiol. 2005; 38:45-50. [PubMed: 16226073]

128. Kohl P, Gourdie RG. Fibroblast-myocyte electrotonic coupling: Does it occur in native cardiac tissue? J Mol Cell Cardiol. 2014; 70:37-46. [PubMed: 24412581]

129. Arnadottir J, Chalfie M. Eukaryotic mechanosensitive channels. Ann Rev Biophys. 2010; 39:111-37. [PubMed: 20192782]

130. Tan JH, Liu W, Saint DA. Trek-like potassium channels in rat cardiac ventricular myocytes are activated by intracellular ATP. J Memb Biol. 2002; 185:201-7.

131. Xian Tao L, Dyachenko V, Zuzarte M, Putzke C, Preisig-Muller R, Isenberg G, Daut J. The stretch-activated potassium channel TREK-1 in rat cardiac ventricular muscle. Cardiovasc Res. 2006; 69:86-97. [PubMed: 16248991]

132. Liu W, Saint DA. Heterogeneous expression of tandem-pore $\mathrm{K}^{+}$channel genes in adult and embryonic rat heart quantified by real-time polymerase chain reaction. Clin Exp Pharm Physiol. 2004; 31:174-178.

133. Honoré, E.; Patel, A. The mechano-gated $\mathrm{K}_{2}$ p channel TREK-1 in the cardiovascular system. In: Kohl, P.; Sachs, F.; Franz, MR., editors. Cardiac Mechano-Electric Coupling and Arrhythmias. 2. Oxford: Oxford University Press; 2011. p. 19-26.

134. Tan JH, Liu W, Saint DA. Differential expression of the mechanosensitive potassium channel TREK-1 in epicardial and endocardial myocytes in rat ventricle. Exp Physiol. 2004; 89:237-42. [PubMed: 15123558]

135. Stones R, Calaghan SC, Billeter R, Harrison SM, White E. Transmural variations in gene expression of stretch-modulated proteins in the rat left ventricle. Pflugers Archiv-Eur J Physiol. 2007; 454:545-549. [PubMed: 17345093]

136. Kelly D, Mackenzie L, Hunter P, Smaill B, Saint DA. Gene expression of stretch-activated channels and mechanoelectric feedback in the heart. Clin Exp Pharma Physiol. 2006; 33:642648.

137. Goonetilleke L, Quayle J. TREK-1 K ${ }^{+}$Channels in the Cardiovascular System: Their Significance and Potential as a Therapeutic Target. Cardiovasc Therapeutics. 2012; 30:e23-e29.

138. Terrenoire C, Lauritzen I, Lesage F, Romey G, Lazdunski M. A TREK-1-like potassium channel in atrial cells inhibited by beta-adrenergic stimulation and activated by volatile anesthetics. Circ Res. 2001; 89:336-342. [PubMed: 11509450]

139. Aimond F, Rauzier JM, Bony C, Vassort G. Simultaneous activation of p38 MAPK and p42/44 MAPK by ATP stimulates the $\mathrm{K}^{+}$current $\mathrm{I}_{\text {TREK }}$ in cardiomyocytes. J Biol Chem. 2000; 275:39110-6. [PubMed: 10993907]

140. Medhurst AD, Rennie G, Chapman CG, Meadows H, Duckworth MD, Kelsell RE, Gloger II, Pangalos MN. Distribution analysis of human two pore domain potassium channels in tissues of the central nervous system and periphery. Mol Brain Res. 2001; 86:101-114. [PubMed: 11165377]

141. Gurney A, Manoury B. Two-pore potassium channels in the cardiovascular system. Eur Biophys J. 2009; 38:305-18. [PubMed: 18449536]

142. Schmidt C, Wiedmann F, Tristram F, Anand P, Wenzel W, Lugenbiel P, Schweizer PA, Katus HA, Thomas D. Cardiac expression and atrial fibrillation-associated remodeling of $\mathrm{K}_{2} \mathrm{p} 2.1$ (TREK-1) $\mathrm{K}^{+}$channels in a porcine model. Life Sci. 2014; 97:107-15. [PubMed: 24345461]

143. Patel AJ, Honore E. Properties and modulation of mammalian $2 \mathrm{P}$ domain $\mathrm{K}^{+}$channels. Trends Neurosci. 2001; 24:339-46. [PubMed: 11356506]

144. Zhang H, Shepherd N, Creazzo TL. Temperature-sensitive TREK currents contribute to setting the resting membrane potential in embryonic atrial myocytes. J Physiol. 2008; 586:3645-56. [PubMed: 18566002]

145. Noel J, Sandoz G, Lesage F. Molecular regulations governing TREK and TRAAK channel functions. Channels (Austin). 2011; 5:402-9. [PubMed: 21829087]

146. Ozaita A, Vega-Saenz de Miera E. Cloning of two transcripts, HKT4.1a and HKT4.1b, from the human two-pore $\mathrm{K}^{+}$channel gene KCNK4 - Chromosomal localization, tissue distribution and functional expression. Mol Brain Res. 2002; 102:18-27. [PubMed: 12191490] 
147. Patel AJ, Honore E, Lesage F, Fink M, Romey G, Lazdunski M. Inhalational anesthetics activate two-pore-domain background $\mathrm{K}^{+}$channels. Nat Neurosci. 1999; 2:422-6. [PubMed: 10321245]

148. Sandoz G, Douguet D, Chatelain F, Lazdunski M, Lesage F. Extracellular acidification exerts opposite actions on TREK1 and TREK2 potassium channels via a single conserved histidine residue. Proc Natl Acad Sci U S A. 2009; 106:14628-33. [PubMed: 19667202]

149. Ge L, Hoa NT, Wilson Z, Arismendi-Morillo G, Kong XT, Tajhya RB, Beeton C, Jadus MR. Big Potassium (BK) ion channels in biology, disease and possible targets for cancer immunotherapy. Int Immunopharmacol. 2014; 22:427-43. [PubMed: 25027630]

150. Takahashi K, Naruse K. Stretch-activated BK channel and heart function. Prog Biophys Mol Biol. 2012; 110:239-244. [PubMed: 23281538]

151. Kawakubo T, Naruse K, Matsubara T, Hotta N, Sokabe M. Characterization of a newly found stretch-activated $\mathrm{K}_{\mathrm{Ca}}, \mathrm{K}_{\mathrm{ATP}}$ channel in cultured chick ventricular myocytes. Am J Physiol Heart Circ Physiol. 1999; 276:H1827-H1838.

152. Iribe G, Jin H, Kaihara K, Naruse K. Effects of axial stretch on sarcolemmal BKCa channels in post-hatch chick ventricular myocytes. Exp Physiol. 2010; 95:699-711. [PubMed: 20176677]

153. Imlach WL, Finch SC, Miller JH, Meredith AL, Dalziel JE. A Role for BK Channels in Heart Rate Regulation in Rodents. Plos One. 2010:5.

154. Xu W, Liu Y, Wang S, McDonald T, Van Eyk JE, Sidor A, O'Rourke B. Cytoprotective role of $\mathrm{Ca}^{2+}$ - activated $\mathrm{K}^{+}$channels in the cardiac inner mitochondrial membrane. Science. 2002; 298:1029-33. [PubMed: 12411707]

155. Tomas M, Vazquez E, Fernandez-Fernandez JM, Subiranaa I, Plata C, Heras M, Vila J, Marrugat J, Valverde MA, Senti M. Genetic variation in the KCNMA1 potassium channel alpha subunit as risk factor for severe essential hypertension and myocardial infarction. J Hypertens. 2008; 26:2147-2153. [PubMed: 18854754]

156. Huang H, Wang W, Liu P, Jiang Y, Zhao Y, Wei H, Niu W. TRPC1 expression and distribution in rat hearts. Eur J Histochem. 2009; 53:e26. [PubMed: 22073358]

157. Iwata Y, Katanosaka Y, Arai Y, Komamura K, Miyatake K, Shigekawa M. A novel mechanism of myocyte degeneration involving the $\mathrm{Ca}^{2+}$-permeable growth factor-regulated channel. J Cell Biol. 2003; 161:957-67. [PubMed: 12796481]

158. Mohl MC, Iismaa SE, Xiao XH, Friedrich O, Wagner S, Nikolova-Krstevski V, Wu JX, Yu ZY, Feneley M, Fatkin D, Allen DG, Graham RM. Regulation of murine cardiac contractility by activation of alpha(1A)-adrenergic receptor-operated $\mathrm{Ca}^{2+}$ entry. Cardiovasc Res. 2011; 91:310 319. [PubMed: 21546445]

159. Coste B, Xiao BL, Santos JS, Syeda R, Grandl J, Spencer KS, Kim SE, Schmidt M, Mathur J, Dubin AE, Montal M, Patapoutian A. Piezo proteins are pore-forming subunits of mechanically activated channels. Nature. 2012; 483:176-U72. [PubMed: 22343900]

160. Suchyna TM, Johnson JH, Hamer K, Leykam JF, Gage DA, Clemo HF, Baumgarten CM, Sachs F. Identification of a peptide toxin from Grammostola spatulata spider venom that blocks cationselective stretch-activated channels. J Gen Physiol. 2000; 115:583-98. [PubMed: 10779316]

161. Volkers L, Mechioukhi Y, Coste B. Piezo channels: from structure to function. Pflugers Arch. 2015; 467:95-9. [PubMed: 25037583]

162. Vogel C, Marcotte EM. Insights into the regulation of protein abundance from proteomic and transcriptomic analyses. Nat Rev Genet. 2012; 13:227-232. [PubMed: 22411467]

163. Inoue R, Jian Z, Kawarabayashi Y. Mechanosensitive TRP channels in cardiovascular pathophysiology. Pharmacology \& Therapeutics. 2009; 123:371-85. [PubMed: 19501617]

164. Spassova MA, Hewavitharana T, Xu W, Soboloff J, Gill DL. A common mechanism underlies stretch activation and receptor activation of TRPC6 channels. Proc Nat Acad Sci USA. 2006; 103:16586-16591. [PubMed: 17056714]

165. Vennekens R. Emerging concepts for the role of TRP channels in the cardiovascular system. J Physiol. 2011; 589:1527-34. [PubMed: 21173080]

166. Riccio A, Medhurst AD, Mattei C, Kelsell RE, Calver AR, Randall AD, Benham CD, Pangalos MN. mRNA distribution analysis of human TRPC family in CNS and peripheral tissues. Mol Brain Res. 2002; 109:95-104. [PubMed: 12531519] 
167. Seo K, Rainer PP, Lee DI, Hao S, Bedja D, Birnbaumer L, Cingolani OH, Kass DA. Hyperactive Adverse Mechanical Stress Responses in Dystrophic Heart Are Coupled to Transient Receptor Potential Canonical 6 and Blocked by cGMP-Protein Kinase G Modulation. Circ Res. 2014; 114:823-32. [PubMed: 24449818]

168. Davis J, Burr AR, Davis GF, Birnbaumer L, Molkentin JD. A TRPC6-dependent pathway for myofibroblast transdifferentiation and wound healing in vivo. Dev Cell. 2012; 23:705-15. [PubMed: 23022034]

169. Maroto R, Raso A, Wood TG, Kurosky A, Martinac B, Hamill OP. TRPC1 forms the stretchactivated cation channel in vertebrate cells. Nat Cell Biol. 2005; 7:179-85. [PubMed: 15665854]

170. Pani B, Ong HL, Brazer SC, Liu X, Rauser K, Singh BB, Ambudkar IS. Activation of TRPC1 by STIM1 in ER-PM microdomains involves release of the channel from its scaffold caveolin-1. Proc Natl Acad Sci U S A. 2009; 106:20087-92. [PubMed: 19897728]

171. Ingueneau C, Huynh UD, Marcheix B, Athias A, Gambert P, Negre-Salvayre A, Salvayre R, Vindis C. TRPC1 is regulated by caveolin-1 and is involved in oxidized LDL-induced apoptosis of vascular smooth muscle cells. J Cell Mol Med. 2009; 13:1620-31. [PubMed: 20187291]

172. Kohl P, Cooper PJ, Holloway H. Effects of acute ventricular volume manipulation on in situ cardiomyocyte cell membrane configuration. Prog Biophys Mol Biol. 2003; 82:221-227. [PubMed: 12732281]

173. Pfeiffer ER, Wright AT, Edwards AG, Stowe JC, McNall K, Tan J, Niesman I, Patel HH, Roth $\mathrm{DM}$, Omens JH, McCulloch AD. Caveolae in ventricular myocytes are required for stretchdependent conduction slowing. J Mol Cell Cardiol. 2014; 76:265-274. [PubMed: 25257915]

174. Friedrich O, Wagner S, Battle AR, Schurmann S, Martinac B. Mechano-regulation of the beating heart at the cellular level - Mechanosensitive channels in normal and diseased heart. Prog Biophys Mol Biol. 2012; 110:226-238. [PubMed: 22959495]

175. Makarewich CA, Zhang H, Davis J, Correll RN, Trappanese DM, Hoffman NE, Troupes CD, Berretta RM, Kubo H, Madesh M, Chen X, Gao E, Molkentin JD, Houser SR. Transient receptor potential channels contribute to pathological structural and functional remodeling after myocardial infarction. Circ Res. 2014; 115:567-80. [PubMed: 25047165]

176. Rubinstein J, Lasko VM, Koch SE, Singh VP, Carreira V, Robbins N, Patel AR, Jiang M, Bidwell P, Kranias EG, Jones WK, Lorenz JN. Novel Role of Transient Receptor Potential Vanilloid 2 in the Regulation of Cardiac Performance. Am J Physiol Heart and Circ Physiol. 2013

177. Muraki K, Iwata Y, Katanosaka Y, Ito T, Ohya S, Shigekawa M, Imaizumi Y. TRPV2 is a component of osmotically sensitive cation channels in murine aortic myocytes. Circ Res. 2003; 93:829-38. [PubMed: 14512441]

178. Lorin C, Vogeli I, Niggli E. Dystrophic cardiomyopathy: role of TRPV2 channels in stretchinduced cell damage. Cardiovasc Res. 2015

179. Morita H, Honda A, Inoue R, Ito Y, Abe K, Nelson MT, Brayden JE. Membrane stretch-induced activation of a TRPM4-like nonselective cation channel in cerebral artery myocytes. J Pharm Sci. 2007; 103:417-426.

180. Watanabe H, Murakami M, Ohba T, Ono K, Ito H. The pathological role of transient receptor potential channels in heart disease. Circ J. 2009; 73:419-27. [PubMed: 19202304]

181. Volk T, Schwoerer AP, Thiessen S, Schultz JH, Ehmke H. A polycystin-2-like large conductance cation channel in rat left ventricular myocytes. Cardiovasc Res. 2003; 58:76-88. [PubMed: 12667948]

182. Anyatonwu GI, Estrada M, Tian X, Somlo S, Ehrlich BE. Regulation of ryanodine receptordependent calcium signaling by polycystin-2. Proc Natl Acad Sci U S A. 2007; 104:6454-9. [PubMed: 17404231]

183. Paavola J, Schliffke S, Rossetti S, Kuo IY, Yuan S, Sun Z, Harris PC, Torres VE, Ehrlich BE. Polycystin-2 mutations lead to impaired calcium cycling in the heart and predispose to dilated cardiomyopathy. J Mol Cell Cardiol. 2013; 58:199-208. [PubMed: 23376035]

184. Hamill OP, McBride DW Jr. The pharmacology of mechanogated membrane ion channels. Pharmacol Rev. 1996; 48:231-52. [PubMed: 8804105]

185. Caldwell RA, Clemo HF, Baumgarten CM. Using gadolinium to identify stretch-activated channels: technical considerations. Am J Physiol Cell Physiol. 1998; 275:C619-C621. 
186. Cooper PJ, Kohl P. Species- and preparation-dependence of stretch effects on sino-atrial node pacemaking. Ann New York Acad Sci. 2005; 1047:324-35. [PubMed: 16093508]

187. Bowman CL, Gottlieb PA, Suchyna TM, Murphy YK, Sachs F. Mechanosensitive ion channels and the peptide inhibitor GsMTx-4: history, properties, mechanisms and pharmacology. Toxicon: Official Journal of the International Society on Toxinology. 2007; 49:249-70. [PubMed: 17157345]

188. Lembrechts R, Brouns I, Schnorbusch K, Pintelon I, Timmermans JP, Adriaensen D. Neuroepithelial bodies as mechanotransducers in the intrapulmonary airway epithelium: involvement of TRPC5. Am J Resp Cell Mol Biol. 2012; 47:315-23.

189. Pan NC, Ma JJ, Peng HB. Mechanosensitivity of nicotinic receptors. Pflugers Archiv-Eur J Physiol. 2012; 464:193-203. [PubMed: 22733356]

190. Bae C, Sachs F, Gottlieb PA. The mechanosensitive ion channel Piezo1 is inhibited by the peptide GsMTx4. Biochemistry. 2011; 50:6295-300. [PubMed: 21696149]

191. Peyronnet R, Martins JR, Duprat F, Demolombe S, Arhatte M, Jodar M, Tauc M, Duranton C, Paulais M, Teulon J, Honore E, Patel A. Piezo1-dependent stretch-activated channels are inhibited by Polycystin-2 in renal tubular epithelial cells. EMBO Reports. 2013

192. Suchyna TM, Tape SE, Koeppe RE 2nd, Andersen OS, Sachs F, Gottlieb PA. Bilayer-dependent inhibition of mechanosensitive channels by neuroactive peptide enantiomers. Nature. 2004; 430:235-40. [PubMed: 15241420]

193. Kamaraju K, Gottlieb PA, Sachs F, Sukharev S. Effects of GsMTx4 on bacterial mechanosensitive channels in inside-out patches from giant spheroplasts. Biophys J. 2010; 99:2870-8. [PubMed: 21044584]

194. Gil V, Gallego D, Moha Ou Maati H, Peyronnet R, Martinez-Cutillas M, Heurteaux C, Borsotto $\mathrm{M}$, Jimenez M. Relative contribution of SKCa and TREK1 channels in purinergic and nitrergic neuromuscular transmission in the rat colon. Am J Physiol Gastrointest Liver Physiol. 2012; 303:G412-23. [PubMed: 22636169]

195. Bagriantsev SN, Ang KH, Gallardo-Godoy A, Clark KA, Arkin MR, Renslo AR, Minor DL Jr. A high-throughput functional screen identifies small molecule regulators of temperature- and mechano-sensitive $\mathrm{K}_{2 \mathrm{P}}$ channels. ACS Chemical Biology. 2013; 8:1841-51. [PubMed: 23738709]

196. Zaugg M, Lucchinetti E, Spahn DR, Pasch T, Schaub MC. Volatile anesthetics mimic cardiac preconditioning by priming the activation of mitochondrial K-ATP channels via multiple signaling pathways. Anesthesiology. 2002; 97:4-14. [PubMed: 12131097]

197. Ripoll C, Lederer WJ, Nichols CG. On the Mechanism of Inhibition of Katp Channels by Glibenclamide in Rat Ventricular Myocytes. Journal of Cardiovascular Electrophysiology. 1993; 4:38-47. [PubMed: 8287235]

198. Harteneck C, Gollasch M. Pharmacological Modulation of Diacylglycerol-Sensitive TRPC3/6/7 Channels. Current Pharmaceutical Biotechnology. 2011; 12:35-41. [PubMed: 20932261]

199. O’Neill J, Brock C, Olesen AE, Andresen T, Nilsson M, Dickenson AH. Unravelling the Mystery of Capsaicin: A Tool to Understand and Treat Pain. Pharmacological Reviews. 2012; 64:939_ 971. [PubMed: 23023032]

200. Koch SE, Gao X, Haar L, Jiang M, Lasko VM, Robbins N, Cai W, Brokamp C, Varma P, Tranter M, Liu Y, Ren X, Lorenz JN, Wang HS, Jones WK, Rubinstein J. Probenecid: novel use as a non-injurious positive inotrope acting via cardiac TRPV2 stimulation. Journal of Molecular and Cellular Cardiology. 2012; 53:134-44. [PubMed: 22561103]

201. Guinamard R, Hof T, Del Negro CA. The TRPM4 channel inhibitor 9-phenanthrol. British Journal of Pharmacology. 2014

202. Syeda R, Xu J, Dubin AE, Coste B, Mathur J, Huynh T, Matzen J, Lao J, Tully DC, Engels IH, Petrassi HM, Schumacher AM, Montal M, Bandell M, Patapoutian A. Chemical activation of the mechanotransduction channel Piezo1. Elife. 2015:4.

203. Seth M, Zhang ZS, Mao L, Graham V, Burch J, Stiber J, Tsiokas L, Winn M, Abramowitz J, Rockman HA, Birnbaumer L, Rosenberg P. TRPC1 Channels Are Critical for Hypertrophic Signaling in the Heart. Circulation Research. 2009; 105:1023-U190. [PubMed: 19797170] 
204. Ohba T, Watanabe H, Murakami M, Takahashi Y, Iino K, Kuromitsu S, Mori Y, Ono K, Iijima T, Ito H. Upregulation of TRPC1 in the development of cardiac hypertrophy. Journal of Molecular and Cellular Cardiology. 2007; 42:498-507. [PubMed: 17174323]

205. Stiber JA, Seth M, Rosenberg PB. Mechanosensitive Channels in Striated Muscle and the Cardiovascular System: Not Quite a Stretch Anymore. Journal of Cardiovascular Pharmacology. 2009; 54:116-122. [PubMed: 19597371]

206. Clemo HF, Stambler BS, Baumgarten CM. Swelling-activated chloride current is persistently activated in ventricular myocytes from dogs with tachycardia-induced congestive heart failure. Circ Res. 1999; 84:157-65. [PubMed: 9933247]

207. Kohl P, Hunter P, Noble D. Stretch-induced changes in heart rate and rhythm: clinical observations, experiments and mathematical models. Prog Biophys Mol Biol. 1999; 71:91-138. [PubMed: 10070213]

208. Zabel M, Koller BS, Sachs F, Franz MR. Stretch-induced voltage changes in the isolated beating heart: importance of the timing of stretch and implications for stretch-activated ion channels. Cardiovasc Res. 1996; 32:120-30. [PubMed: 8776409]

209. Quinn TA, Kohl P. Combining wet and dry research: experience with model development for cardiac mechano-electric structure-function studies. Cardiovasc Res. 2013; 97:601-11. [PubMed: 23334215]

210. Healy SN, McCulloch AD. An ionic model of stretch-activated and stretch-modulated currents in rabbit ventricular myocytes. Europace. 2005; 7(Suppl 2):128-34. [PubMed: 16102510]

211. Trayanova NA, Constantino J, Gurev V. Models of stretch-activated ventricular arrhythmias. J Electrocardiol. 2010; 43:479-85. [PubMed: 20638670]

212. Kohl P, Day K, Noble D. Cellular mechanisms of cardiac mechano-electric feedback in a mathematical model. Can J Cardiol. 1998; 14:111-9. [PubMed: 9487283]

213. Garny A, Kohl P. Mechanical induction of arrhythmias during ventricular repolarization: modeling cellular mechanisms and their interaction in two dimensions. Ann N Y Acad Sci. 2004; 1015:133-43. [PubMed: 15201155]

214. Li W, Kohl P, Trayanova N. Induction of ventricular arrhythmias following mechanical impact: a simulation study in 3D. J Mol Histol. 2004; 35:679-86. [PubMed: 15614623]

215. Quinn TAHH, Lee P, Kohl P. Mechanically-induced ectopy via stretch-activated cationnonselective channels is caused by local tissue deformation and results in ventricular fibrillation if triggered on the repolarization wave-edge. JACC EP. 2015 in review.

216. Sokabe M, Sachs F, Jing ZQ. Quantitative video microscopy of patch clamped membranes stress, strain, capacitance, and stretch channel activation. Biophys J. 1991; 59:722-8. [PubMed: 1710939]

217. Le Guennec JY, Peineau N, Argibay JA, Mongo KG, Garnier D. A new method of attachment of isolated mammalian ventricular myocytes for tension recording: length dependence of passive and active tension. J Mol Cell Cardiol. 1990; 22:1083-93. [PubMed: 2095433]

218. Nishimura S, Seo K, Nagasaki M, Hosoya Y, Yamashita H, Fujita H, Nagai R, Sugiura S. Responses of single-ventricular myocytes to dynamic axial stretching. Prog Biophys Mol Biol. 2008; 97:282-97. [PubMed: 18471867]

219. Omens JH, MacKenna DA, McCulloch AD. Measurement of strain and analysis of stress in resting rat left ventricular myocardium. J Biomech. 1993; 26:665-76. [PubMed: 8514812]

220. Hales PW, Schneider JE, Burton RA, Wright BJ, Bollensdorff C, Kohl P. Histo-anatomical structure of the living isolated rat heart in two contraction states assessed by diffusion tensor MRI. Prog Biophys Mol Biol. 2012; 110:319-30. [PubMed: 23043978]

221. Guo J, Sachs F, Meng F. Fluorescence-based force/tension sensors: a novel tool to visualize mechanical forces in structural proteins in live cells. Antioxid Redox Signal. 2014; 20:986-99. [PubMed: 24205787]

222. Slovut DP, Wenstrom JC, Moeckel RB, Wilson RF, Osborn JW, Abrams JH. Respiratory sinus dysrhythmia persists in transplanted human hearts following autonomic blockade. Clin Exp Pharmacol Physiol. 1998; 25:322-30. [PubMed: 9612658] 
223. Dibb KM, Graham HK, Venetucci LA, Eisner DA, Trafford AW. Analysis of cellular calcium fluxes in cardiac muscle to understand calcium homeostasis in the heart. Cell Calcium. 2007; 42:503-12. [PubMed: 17509680]

224. Gannier F, White E, Garnier, Le Guennec JY. A possible mechanism for large stretch-induced increase in $\left[\mathrm{Ca}^{2+}\right]$ i in isolated guinea-pig ventricular myocytes. Cardiovasc Res. 1996; 32:15867. [PubMed: 8776413]

225. Cannell MB. Pulling on the heart strings: a new mechanism within Starling's law of the heart? Circ Res. 2009; 104:715-6. [PubMed: 19325158]

226. Calaghan $\mathrm{S}$, White E. Activation of $\mathrm{Na}^{+}-\mathrm{H}^{+}$exchange and stretch-activated channels underlies the slow inotropic response to stretch in myocytes and muscle from the rat heart. J Physiol. 2004; 559:205-14. [PubMed: 15235080]

227. Zoll PM, Belgard AH, Weintraub MJ, Frank HA. External mechanical cardiac stimulation. N Engl J Med. 1976; 294:1274-5. [PubMed: 772432]

228. Cohn PF, Angoff GH, Zoll PM, Sloss LJ, Markis JE, Graboys TB, Green LH, Braunwald E. A new, noninvasive technique for inducing post-extrasystolic potentiation during echocardiography. Circulation. 1977; 56:598-605. [PubMed: 902386]

229. Pellis T, Kohl P. Antiarrhythmic effects of acute mechanical stimulation. Cardiac mechanoelectric coupling and arrhythmias. 2011; 2:361-8.

230. Levine JH, Guarnieri T, Kadish AH, White RI, Calkins H, Kan JS. Changes in myocardial repolarization in patients undergoing balloon valvuloplasty for congenital pulmonary stenosis: evidence for contraction-excitation feedback in humans. Circulation. 1988; 77:70-7. [PubMed: 3335073]

231. Gallacher DJ, Van de Water A, van der Linde H, Hermans AN, Lu HR, Towart R, Volders PG. In vivo mechanisms precipitating torsades de pointes in a canine model of drug-induced long-QT1 syndrome. Cardiovasc Res. 2007; 76:247-56. [PubMed: 17669388]

232. Link MS, Wang PJ, Pandian NG, Bharati S, Udelson JE, Lee MY, Vecchiotti MA, VanderBrink BA, Mirra G, Maron BJ, Estes NA 3rd. An experimental model of sudden death due to lowenergy chest-wall impact (commotio cordis). N Engl J Med. 1998; 338:1805-11. [PubMed: 9632447]

233. Link MS. Commotio cordis: ventricular fibrillation triggered by chest impact-induced abnormalities in repolarization. Circ Arrhythm Electrophysiol. 2012; 5:425-32. [PubMed: 22511659]

234. Alsheikh-Ali AA, Akelman C, Madias C, Link MS. Endocardial mapping of ventricular fibrillation in commotio cordis. Heart Rhythm. 2008; 5:1355-6. [PubMed: 18693072]

235. Walters TE, Lee G, Spence S, Larobina M, Atkinson V, Antippa P, Goldblatt J, O'Keefe M, Sanders P, Kistler PM, Kalman JM. Acute atrial stretch results in conduction slowing and complex signals at the pulmonary vein to left atrial junction: insights into the mechanism of pulmonary vein arrhythmogenesis. Circ Arrhythm Electrophysiol. 2014; 7:1189-97. [PubMed: 25516579]

236. Sparks PB, Mond HG, Vohra JK, Yapanis AG, Grigg LE, Kalman JM. Mechanical remodeling of the left atrium after loss of atrioventricular synchrony. A long-term study in humans. Circulation. 1999; 100:1714-21. [PubMed: 10525491]

237. Wijffels MC, Kirchhof CJ, Dorland R, Power J, Allessie MA. Electrical remodeling due to atrial fibrillation in chronically instrumented conscious goats: roles of neurohumoral changes, ischemia, atrial stretch, and high rate of electrical activation. Circulation. 1997; 96:3710-20. [PubMed: 9396475]

238. Quintanilla JG, Moreno J, Archondo T, Usandizaga E, Molina-Morua R, Rodriguez-Bobada C, Gonzalez P, Garcia-Torrent MJ, Filgueiras-Rama D, Perez-Castellano N, Macaya C, PerezVillacastin J. Increased intraventricular pressures are as harmful as the electrophysiological substrate of heart failure in favoring sustained reentry in the swine heart. Heart Rhythm. 2015

239. Franz MR, Burkhoff D, Yue DT, Sagawa K. Mechanically induced action potential changes and arrhythmia in isolated and in situ canine hearts. Cardiovasc Res. 1989; 23:213-23. [PubMed: 2590905] 
240. Salameh A, Karl S, Djilali H, Dhein S, Janousek J, Daehnert I. Opposing and synergistic effects of cyclic mechanical stretch and alpha- or beta-adrenergic stimulation on the cardiac gap junction protein Cx43. Pharmacol Res. 2010; 62:506-13. [PubMed: 20705136]

241. John B, Stiles MK, Kuklik P, Brooks AG, Chandy ST, Kalman JM, Sanders P. Reverse remodeling of the atria after treatment of chronic stretch in humans: implications for the atrial fibrillation substrate. J Am Coll Cardiol. 2010; 55:1217-26. [PubMed: 20298929]

242. Mondry A, Swynghedauw B. Biological adaptation of the myocardium to chronic mechanical overload. Molecular determinants of the autonomic nervous system. Eur Heart J. 1995; 16(Suppl I):64-73. [PubMed: 8829959]

243. Waxman MB, Wald RW, Finley JP, Bonet JF, Downar E, Sharma AD. Valsalva termination of ventricular tachycardia. Circulation. 1980; 62:843-51. [PubMed: 6773699]

244. Ashikaga H, Mickelsen SR, Ennis DB, Rodriguez I, Kellman P, Wen H, McVeigh ER. Electromechanical analysis of infarct border zone in chronic myocardial infarction. Am J Physiol Heart Circ Physiol. 2005; 289:H1099-105. [PubMed: 15908463]

245. Jie X, Gurev V, Trayanova N. Mechanisms of mechanically induced spontaneous arrhythmias in acute regional ischemia. Circ Res. 2010; 106:185-92. [PubMed: 19893011]

246. Lab, CBM. Cardiac Mechano-Electric Coupling and Arrhythmias. 2. OUP; Oxford: 2011. Stretch effects on potassium accumulation and alternans in pathological myocardium; p. 173-179.

247. Schott E. Über Ventrikelstillstand (Adam-Stokes'sche Anfälle) nebst Bemerkungen über andersartige Arrhythmien passagerer Natur.("On Ventricular Standstill (Adam-Stokes Attacks) together with other Arrhythmias of Temporary Nature.”). Dt Arch klin Med. 1920:211-229.

248. Li W, Kohl P, Trayanova N. Myocardial ischemia lowers precordial thump efficacy: an inquiry into mechanisms using three-dimensional simulations. Heart Rhythm. 2006; 3:179-86. [PubMed: 16443533]

249. Pellis T, Kohl P. Extracorporeal cardiac mechanical stimulation: precordial thump and precordial percussion. Br Med Bull. 2010; 93:161-77. [PubMed: 20007187]

250. Nehme Z, Andrew E, Bernard SA, Smith K. Treatment of monitored out-of-hospital ventricular fibrillation and pulseless ventricular tachycardia utilising the precordial thump. Resuscitation. 2013; 84:1691-6. [PubMed: 23994203]

251. Pellis T, Kette F, Lovisa D, Franceschino E, Magagnin L, Mercante WP, Kohl P. Utility of precordial thump for treatment of out of hospital cardiac arrest: a prospective study. Resuscitation. 2009; 80:17-23. [PubMed: 19010581]

252. Amir O, Schliamser JE, Nemer S, Arie M. Ineffectiveness of precordial thump for cardioversion of malignant ventricular tachyarrhythmias. Pacing Clin Electrophysiol. 2007; 30:153-6. [PubMed: 17338709]

253. Haman L, Parizek P, Vojacek J. Precordial thump efficacy in termination of induced ventricular arrhythmias. Resuscitation. 2009; 80:14-16. [PubMed: 18952350]

254. Sayre MR, Koster RW, Botha M, Cave DM, Cudnik MT, Handley AJ, Hatanaka T, Hazinski MF, Jacobs I, Monsieurs K, Morley PT, Nolan JP, Travers AH. Adult Basic Life Support Chapter C Part 5: Adult basic life support: 2010 International Consensus on Cardiopulmonary Resuscitation and Emergency Cardiovascular Care Science With Treatment Recommendations. Circulation. 2010; 122:S298-324. [PubMed: 20956253]

255. Eich C, Bleckmann A, Schwarz SK. Percussion pacing--an almost forgotten procedure for haemodynamically unstable bradycardias? A report of three case studies and review of the literature. Br J Anaesth. 2007; 98:429-33. [PubMed: 17327252]

256. Madias C, Maron BJ, Alsheikh-Ali AA, Rajab M, Estes NA 3rd, Link MS. Precordial thump for cardiac arrest is effective for asystole but not for ventricular fibrillation. Heart Rhythm. 2009; 6:1495-500. [PubMed: 19968931]

257. Monteleone PP, Alibertis K, Brady WJ. Emergent precordial percussion revisited--pacing the heart in asystole. Am J Emerg Med. 2011; 29:563-5. [PubMed: 20825861]

258. Gottlieb PA, Bae C, Sachs F. Gating the mechanical channel Piezo1: a comparison between whole-cell and patch recording. Channels (Austin). 2012; 6:282-9. [PubMed: 22790451] 
259. Retailleau K, Duprat F, Arhatte M, Ranade SS, Peyronnet R, Martins JR, Jodar M, Moro C, Offermanns S, Feng Y, Demolombe S, Patel A, Honore E. Piezo1 in Smooth Muscle Cells Is Involved in Hypertension-Dependent Arterial Remodeling. Cell Rep. 2015

260. Sheetz MP. Cell control by membrane-cytoskeleton adhesion. Nat Rev Mol Cell Biol. 2001; 2:392-6. [PubMed: 11331914]

261. Sachs F. Mechanical transduction by ion channels; a cautionary tale. World Journal of Neurology. 2015:5.

262. Evans EA, Skalak R. Mechanics and thermodynamics of biomembranes: part 1. CRC Crit Rev Bioeng. 1979; 3:181-330. [PubMed: 393460]

263. Nichol JA, Hutter OF. Tensile strength and dilatational elasticity of giant sarcolemmal vesicles shed from rabbit muscle. J Physiol. 1996; 493(Pt 1):187-98. [PubMed: 8735704]

264. Morris CE, Homann U. Cell surface area regulation and membrane tension. J Membr Biol. 2001; 179:79-102. [PubMed: 11220366]

265. Groulx N, Boudreault F, Orlov SN, Grygorczyk R. Membrane reserves and hypotonic cell swelling. J Membr Biol. 2006; 214:43-56. [PubMed: 17598067]

266. Raucher D, Sheetz MP. Characteristics of a membrane reservoir buffering membrane tension. Biophys J. 1999; 77:1992-2002. [PubMed: 10512819]

267. Kozera L, White E, Calaghan S. Caveolae act as membrane reserves which limit mechanosensitive $\mathrm{I}(\mathrm{Cl}$,swell) channel activation during swelling in the rat ventricular myocyte. PLoS One. 2009; 4:e8312. [PubMed: 20011535]

268. Dai J, Sheetz MP, Wan X, Morris CE. Membrane tension in swelling and shrinking molluscan neurons. J Neurosci. 1998; 18:6681-92. [PubMed: 9712640]

269. Sachs F. Stretch-Activated Ion Channels: What Are They? Physiology. 2010; 25:50-56. [PubMed: 20134028]

270. Bigay J, Casella JF, Drin G, Mesmin B, Antonny B. ArfGAP1 responds to membrane curvature through the folding of a lipid packing sensor motif. EMBO J. 2005; 24:2244-53. [PubMed: 15944734]

271. Eyckmans J, Boudou T, Yu X, Chen CS. A hitchhiker's guide to mechanobiology. Dev Cell. 2011; 21:35-47. [PubMed: 21763607]

272. Cruickshank CC, Minchin RF, Le Dain AC, Martinac B. Estimation of the pore size of the largeconductance mechanosensitive ion channel of Escherichia coli. Biophys J. 1997; 73:1925-31. [PubMed: 9336188]

273. Wagner E, Lauterbach MA, Kohl T, Westphal V, Williams GS, Steinbrecher JH, Streich JH, Korff B, Tuan HT, Hagen B, Luther S, Hasenfuss G, Parlitz U, Jafri MS, Hell SW, Lederer WJ, Lehnart SE. Stimulated emission depletion live-cell super-resolution imaging shows proliferative remodeling of T-tubule membrane structures after myocardial infarction. Circ Res. 2012; 111:402-14. [PubMed: 22723297]

274. Savio-Galimberti E, Frank J, Inoue M, Goldhaber JI, Cannell MB, Bridge JH, Sachse FB. Novel features of the rabbit transverse tubular system revealed by quantitative analysis of threedimensional reconstructions from confocal images. Biophys J. 2008; 95:2053-62. [PubMed: 18487298]

275. Cannell MB, Crossman DJ, Soeller C. Effect of changes in action potential spike configuration, junctional sarcoplasmic reticulum micro-architecture and altered t-tubule structure in human heart failure. J Muscle Res Cell Motil. 2006; 27:297-306. [PubMed: 16897575]

276. Suchyna TM, Markin VS, Sachs F. Biophysics and structure of the patch and the gigaseal. Biophys J. 2009; 97:738-47. [PubMed: 19651032]

277. Meng F, Suchyna TM, Sachs F. A fluorescence energy transfer-based mechanical stress sensor for specific proteins in situ. The FEBS Journal. 2008; 275:3072-87. [PubMed: 18479457]

278. Meng F, Sachs F. Visualizing dynamic cytoplasmic forces with a compliance-matched FRET sensor. J Cell Sci. 2011; 124:261-9. [PubMed: 21172803]

279. Wang Y, Liu Y, Deberg HA, Nomura T, Hoffman MT, Rohde PR, Schulten K, Martinac B, Selvin PR. Single molecule FRET reveals pore size and opening mechanism of a mechanosensitive ion channel. Elife. 2014; 3:e01834. [PubMed: 24550255] 
280. Hirata H, Tatsumi H, Hayakawa K, Sokabe M. Non-channel mechanosensors working at focal adhesion-stress fiber complex. Pflugers Arch. 2015; 467:141-55. [PubMed: 24965068]

281. Israeli-Rosenberg S, Chen C, Li R, Deussen DN, Niesman IR, Okada H, Patel HH, Roth DM, Ross RS. Caveolin modulates integrin function and mechanical activation in the cardiomyocyte. FASEB J. 2015; 29:374-84. [PubMed: 25366344]

282. Chai Q, Wang XL, Zeldin DC, Lee HC. Role of caveolae in shear stress-mediated endotheliumdependent dilation in coronary arteries. Cardiovasc Res. 2013; 100:151-159. [PubMed: 23787000]

283. McNary TG, Spitzer KW, Holloway H, Bridge JHB, Kohl P, Sachse FB. Mechanical modulation of the transverse tubular system of ventricular cardiomyocytes. Prog Biophys Mol Biol. 2012; 110:218-225. [PubMed: 22884710] 


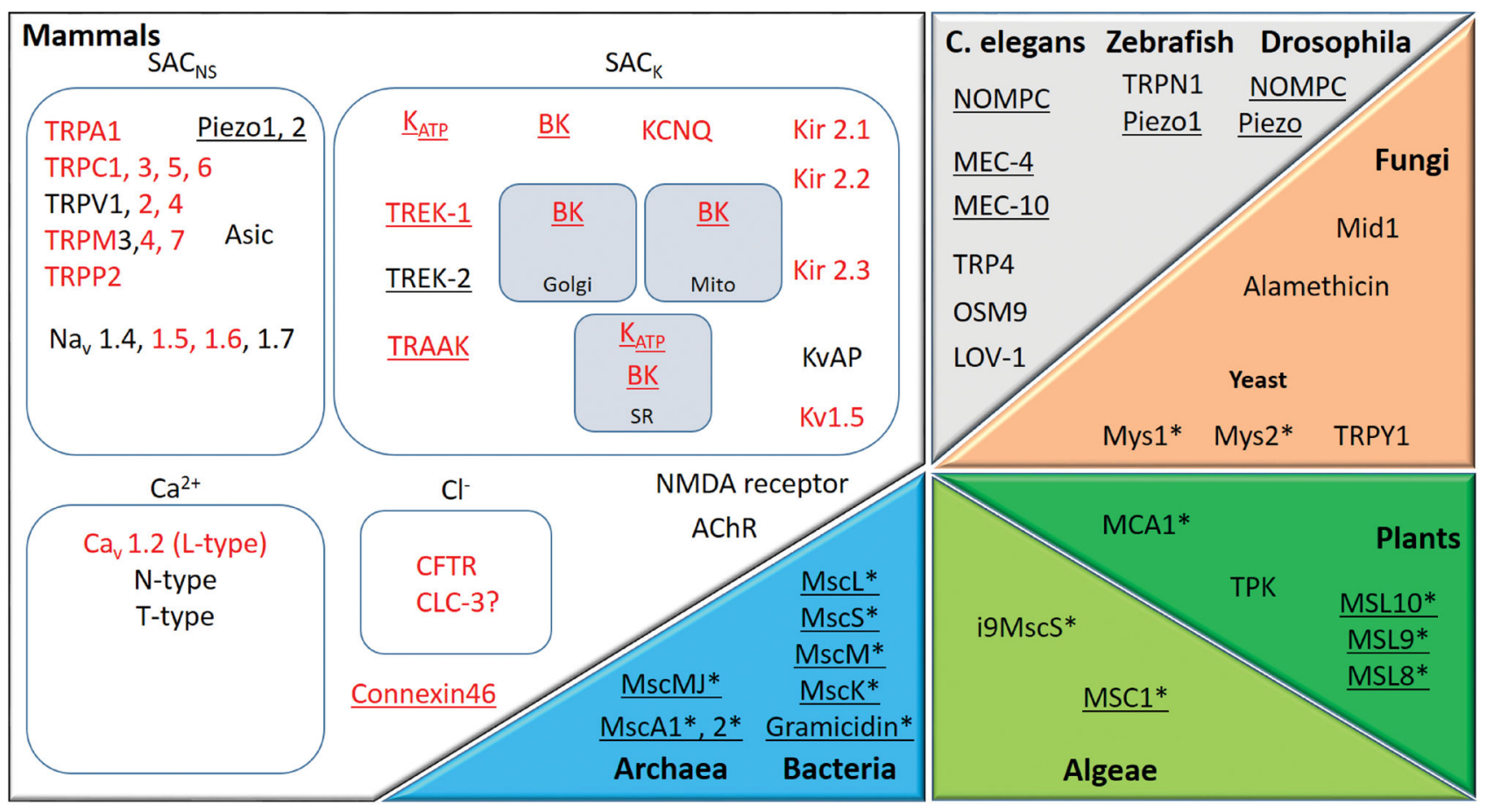

Figure 1.

MGC and mechanically modulated channel (MMC) candidates are present throughout living organisms. Several mammalian channels have homologues in other organisms: e.g.

NOMPC, OSM9, TRP4, TRPY1 and LOV-1 are TRP homologues; MEC channels are members of the DEG/ENaC superfamily whose mammalian representatives are ASIC channels; TPK is a homologue of $\mathrm{K}_{2 \mathrm{P}}$ channels; Mid1 is homologous to voltage-gated calcium channels. In red: channels expressed in the heart; underlined: channels clearly identified as MGC; channels with no known mammalian homologues are marked by *. "SAC $\mathrm{NS}_{\mathrm{N}}$ ": stretch-activated channels, cation non selective; "SAC $\mathrm{K}_{\mathrm{K}}$ ": stretch-activated channels, potassium selective; "Mito": mitochondria; "SR": sarcoplasmic reticulum. Only a selection of the more well-known channels and receptors is presented; protein names for mammals are explained in Section 2. 


\begin{tabular}{|c|c|c|c|c|}
\hline \multicolumn{2}{|c|}{ MMC } & \multicolumn{3}{|c|}{ MGC } \\
\hline Voltage & Ligand & \multicolumn{2}{|c|}{ SAC } & VAC \\
\hline KvATP & \multirow[b]{2}{*}{ NMDA receptor } & $\mathrm{SAC}_{\mathrm{K}}$ & $\mathrm{SAC}_{\mathrm{NS}}$ & TRPA1 \\
\hline Kv1.5 & & TREK-1, 2 & Piezo1 & TRPC1, 3, 6 \\
\hline Kir2.1, 2.2, 2.3 & $\mathrm{AChR}$ & TRAAK & \multirow[t]{3}{*}{ Piezo2 } & TRPV1, 2, 4 \\
\hline L-type & & BK? & & TRPM3, 4, 7 \\
\hline \multirow[t]{2}{*}{ Nav1.4, 1.5, 1.6, 1.7 } & \multicolumn{2}{|c|}{$\overline{K_{\text {ATP }}}$} & & TRPP2 \\
\hline & & & Connexin46 & ASIC \\
\hline
\end{tabular}

Figure 2.

Mechanically Modulated Channels (MMC) versus Mechanically Gated Channels (MGC). Presentation includes channels understood to be activated by transmembrane voltage, ligands, stretch (SAC: Stretch Activated Channel) or intracellular volume change (VAC: Volume Activated Channel). In red: channels expressed in the heart. 

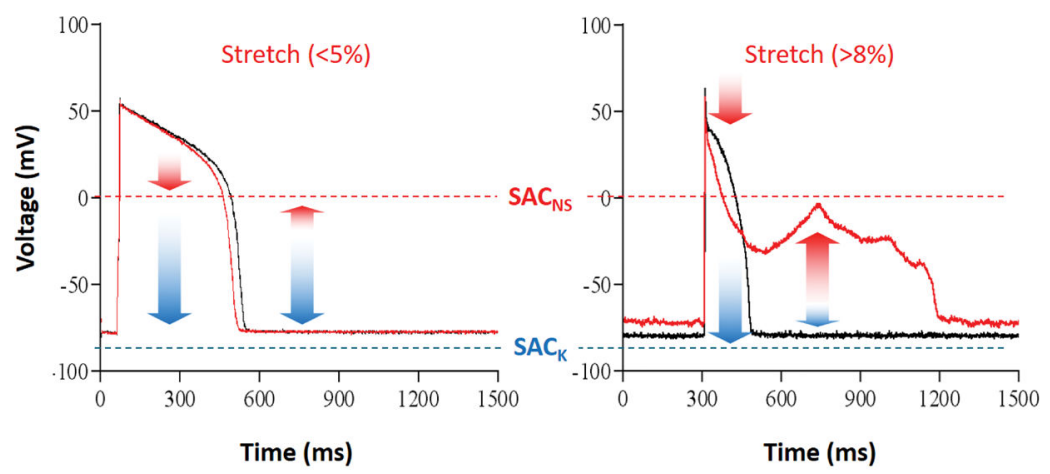

Figure 3.

Stretch greatly modifies the action potential (AP). Representative recordings showing the effect of stretch intensity on AP and resting membrane potential in single isolated cardiomyocytes. Stretch was applied during the entire duration of recordings, scaled to control cell length (left: moderate stretch, right: large stretch); control recordings: black; stretch: red. Red arrows indicate putative contributions of $\mathrm{SAC}_{\mathrm{NS}}$, blue arrows represent potential effects of $\mathrm{SAC}_{\mathrm{K}}$. Adapted from Kohl et al. ${ }^{3}$ 


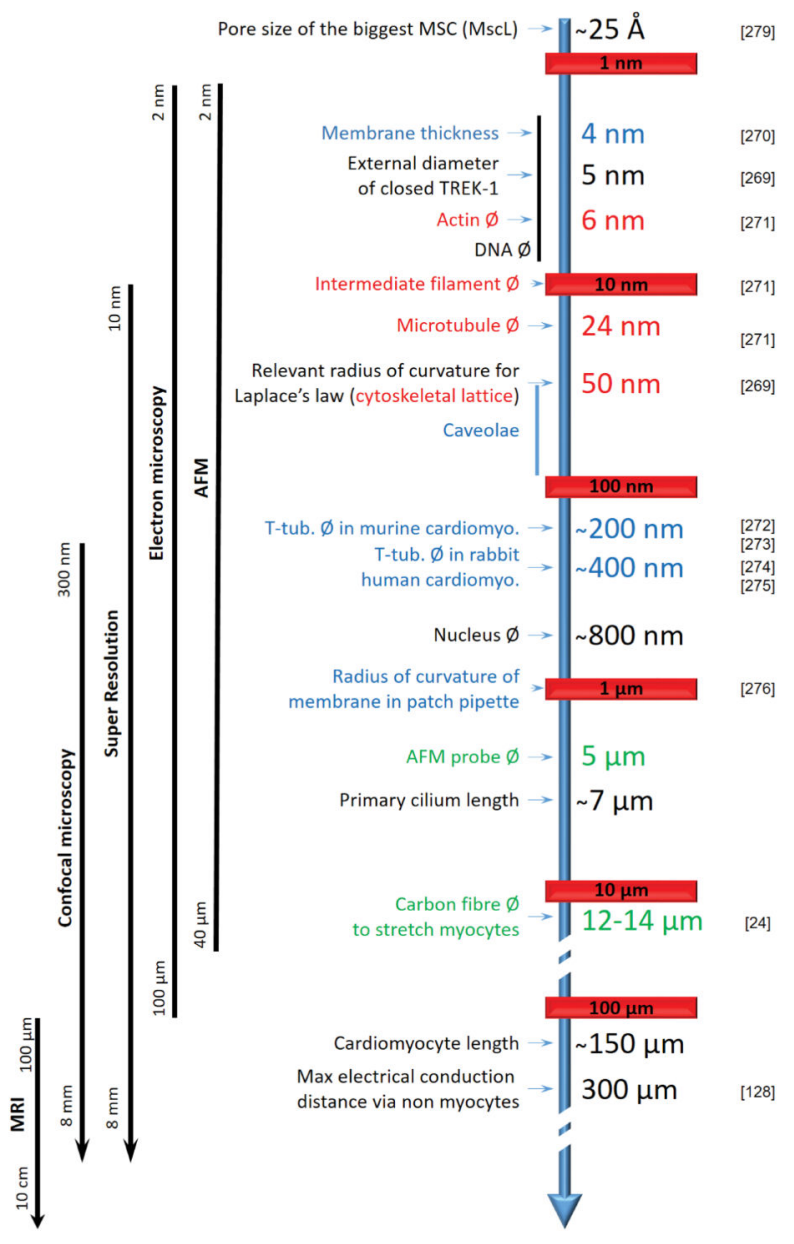

Figure 4.

size matters. Strain is greatly influenced by size and shape of affected structures, and spans all scales from nano to macro. Tools to study mechano-sensors are listed on the left in parallel with milestones. Membrane (blue), cytoskeleton (red), measuring probes (green), others structures (black) are annotaed. MRI: Magnetic Resonance Imaging, AFM: Atomic Fore Microscopy, $\varnothing$ : diameter. 